\title{
Gene expression responses in male fathead minnows exposed to binary mixtures of an estrogen and antiestrogen Natàlia Garcia-Reyero ${ }^{1,8}$, Kevin J Kroll11, Li Liu ${ }^{2}$, Edward F Orlando3, Karen H Watanabe ${ }^{4}$, María S Sepúlveda5, Daniel L Villeneuve ${ }^{6}$, Edward J Perkins ${ }^{7}$, Gerald T Ankley ${ }^{6}$ and Nancy D Denslow*1
}

Address: ${ }^{1}$ Department of Physiological Sciences and Center for Environmental and Human Toxicology, University of Florida, Gainesville, FL 32611, USA, ${ }^{2}$ ICBR, University of Florida, Gainesville, FL 32611, USA, ${ }^{3}$ Department of Animal \& Avian Sciences, University of Maryland, College Park, MD 20742, USA, ${ }^{4}$ Division of Environmental and Biomolecular Systems, Oregon Health \& Science University, West Campus, Beaverton, OR, 97006, USA, ${ }^{5}$ Department of Forestry \& Natural Resources, Purdue University, Lafayette, IN, 47907, USA, ${ }^{6}$ U.S. Environmental Protection Agency, ORD, NHEERL, MED, Duluth, MN, 55804, USA, ${ }^{7}$ Environmental Laboratory, US Army Engineer Research and Development Center, Vicksburg, MS, 39180, USA and ${ }^{8}$ Current address: Department of Chemistry, Jackson State University, Jackson, MS 39217, USA

Email: Natàlia Garcia-Reyero - natalia@ccmsi.us; Kevin J Kroll - krollk@ufl.edu; Li Liu - liliu@biotech.ufl.edu; Edward F Orlando - eorlando@umd.edu; Karen H Watanabe - watanabe@ebs.ogi.edu; María S Sepúlveda - mssepulv@purdue.edu; Daniel L Villeneuve - Villeneuve.Dan@epamail.epa.gov; Edward J Perkins - Edward.J.Perkins@erdc.usace.army.mil; Gerald T Ankley - Ankley.Gerald@epamail.epa.gov; Nancy D Denslow* - ndenslow@ufl.edu

* Corresponding author

Published: 13 July 2009

BMC Genomics 2009, 10:308 doi:10.1/86/|47|-2/64-10-308
Received: 30 December 2008

Accepted: 13 July 2009

This article is available from: http://www.biomedcentral.com//47/-2/64//0/308

(c) 2009 Garcia-Reyero et al; licensee BioMed Central Ltd.

This is an Open Access article distributed under the terms of the Creative Commons Attribution License (http://creativecommons.org/licenses/by/2.0), which permits unrestricted use, distribution, and reproduction in any medium, provided the original work is properly cited.

\begin{abstract}
Background: Aquatic organisms are continuously exposed to complex mixtures of chemicals, many of which can interfere with their endocrine system, resulting in impaired reproduction, development or survival, among others. In order to analyze the effects and mechanisms of action of estrogen/anti-estrogen mixtures, we exposed male fathead minnows (Pimephales promelas) for 48 hours via the water to 2, 5, I0, and $50 \mathrm{ng}$ I7 $\alpha$-ethinylestradiol $\left(\mathrm{EE}_{2}\right) / \mathrm{L}, 100 \mathrm{ng} Z \mathrm{ZM} \mathrm{I89,I54/L} \mathrm{(a}$ potent antiestrogen known to block activity of estrogen receptors) or mixtures of 5 or $50 \mathrm{ng} \mathrm{EE}_{2} /$ L with $100 \mathrm{ng}$ ZM 189,154/L. We analyzed gene expression changes in the gonad, as well as hormone and vitellogenin plasma levels.
\end{abstract}

Results: Steroidogenesis was down-regulated by $\mathrm{EE}_{2}$ as reflected by the reduced plasma levels of testosterone in the exposed fish and down-regulation of genes in the steroidogenic pathway. Microarray analysis of testis of fathead minnows treated with $5 \mathrm{ng} \mathrm{EE}_{2} / \mathrm{L}$ or with the mixture of 5

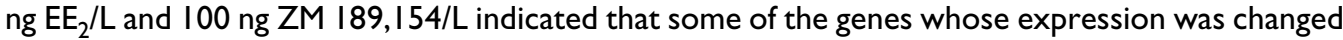
by $E_{2}$ were blocked by $Z M \quad 189,154$, while others were either not blocked or enhanced by the mixture, generating two distinct expression patterns. Gene ontology and pathway analysis programs were used to determine categories of genes for each expression pattern.

Conclusion: Our results suggest that response to estrogens occurs via multiple mechanisms, including canonical binding to soluble estrogen receptors, membrane estrogen receptors, and other mechanisms that are not blocked by pure antiestrogens. 


\section{Background}

Worldwide, aquatic organisms are exposed to mixtures of chemicals (e.g., pharmaceuticals, pesticides, and industrial chemicals), which enter the environment through wastewaters as well as other sources. Many of these chemicals are capable of interfering with endocrine signaling via a complex array of biomolecules (e.g., hormones) to regulate processes such as reproduction and metabolism. These endocrine disrupting chemicals (EDCs) alter signaling through a variety of mechanisms including binding to soluble sex hormone receptors or membrane receptors and acting as agonists or antagonists, or by inhibiting/ inducing enzymes and proteins, which produce naturally occurring steroid hormones. Compared to other chemical pollutants, EDCs are likely to have effects at relatively low concentrations [1].

Of the EDCs, xenoestrogens have been the most studied because estrogenic effects have been observed in field studies of fish and wildlife populations [2-4]. In oviparous animals such as fish, a sensitive and robust biomarker (i.e. vitellogenin, VTG) exists for evaluating exposure to xenoestrogens. Early studies of sewage treatment effluents attributed the feminization of fish to exposure to mixtures of natural (e.g., estrone and $17 \beta$-estradiol, $E_{2}$ ) and synthetic (e.g., 17 $\alpha$-ethinylestradiol, $\mathrm{EE}_{2}$ ) estrogens $[1,5]$. One of the most potent estrogens known is $\mathrm{EE}_{2}$, a pharmaceutical that is one of the active ingredients in contraceptives. Indeed, $\mathrm{EE}_{2}$ has been shown to be up to 27 times more potent than $\mathrm{E}_{2}$ [6]. In the United States, $\mathrm{EE}_{2}$ use is estimated at $170 \mathrm{~kg} / \mathrm{yr}$ [7]; and in the United Kingdom, its use is roughly $26 \mathrm{~kg} / \mathrm{yr}$ [8]. Measured $\mathrm{EE}_{2}$ surface water concentrations in the United States, United Kingdom, The Netherlands, and Germany range from 0.5 to 15 $\mathrm{ng} / \mathrm{L}$ [7], and it has been frequently measured in United States streams [9].

In laboratory studies, exposures of fish to environmentally relevant $\mathrm{EE}_{2}$ concentrations cause a variety of effects that include testis-ova (the appearance of both sperm and egg follicles in the testis), increased plasma VTG concentrations, reduced gonad size, and altered sex ratios. Studies have used exposure durations of various lengths, including short ( $\leq 7$ days of exposure), intermediate ( 7 to 28 days exposure), and long (> 28 days) term. In female fish, environmentally relevant $\mathrm{EE}_{2}$ exposures can increase plasma VTG concentrations [10-12] and decrease egg production [13] in long-term studies, but seem to have little or no effect on fecundity for intermediate length exposures $[10,12]$. In some studies, long-term exposure to $\mathrm{EE}_{2}$ completely inhibits spawning in fish $[11,14]$.

Long-term $\mathrm{EE}_{2}$ exposure of embryos has been shown to disrupt sexual differentiation of male fish. Fathead minnow (FHM, Pimephales promelas) embryos continuously exposed to $\mathrm{EE}_{2}$ concentrations as low as $4 \mathrm{ng} / \mathrm{L}$ did not clearly sexually differentiate at 176 days post-fertilization [12]. Similarly, continuous exposure of zebrafish (Danio rerio) embryos to $\mathrm{EE}_{2}$ concentrations as low as $3 \mathrm{ng} / \mathrm{L}$ resulted in all fish having ovaries [11]. $\mathrm{EE}_{2}$ also reduced gonad size and circulating testosterone (T) levels [15], increased VTG $[11,12,16]$, and arrested the developmental transition of the gonads of genetically male zebrafish [11]. The steroid also can cause hepatotoxicity, nephrotoxicity and gonadotoxicity [17]. Overall, studies to date suggest that exposure to $\mathrm{EE}_{2}$ elicits adverse effects on fish reproduction primarily through the feminization of male fish, and in females through cessation of spawning. These findings have alerted scientists and environmental regulators to the potential for severe adverse effects on aquatic populations [18], and, potentially, aquatic ecosystems [19]. The current research was conducted to provide a better understanding of the mechanistic basis for effects of estrogenic chemicals in fish.

Effects on gene expression have been investigated with short- and intermediate-term exposures to $\mathrm{EE}_{2}$ [20-22] in order to discover gene expression profiles indicative of potential adverse effects. In addition to affecting gene expression through soluble nuclear hormone receptors, it is now clear that sex hormones can also bind directly to membrane receptors and enact immediate changes in signaling via non-genomic pathways $[23,24]$. Specific sex hormone receptors in membranes have been identified in fish testis and ovaries for $\mathrm{E}_{2}[25,26], \mathrm{T}$ [27] and progestins [28]. It is difficult to distinguish gene transcription regulation through classical receptor-dependent mechanisms, where estrogen receptor homo- and heterodimers bind to estrogen receptor elements in promoters, from action due to binding of estrogen receptors (ERs) to other transcription factors that activate through $\mathrm{Sp} 1$ (stimulatory protein 1) or AP-1 (activating protein 1) binding sites or that activate signaling cascades that start at the membrane. ZM189,154 (ZM) was produced by Astra-Zeneca (Alderly Park, Cheshire, UK) and there are reports that it functions as a "pure" antiestrogen in mammals [29] and in fish $[30,31]$, meaning that it will bind to and inhibit activation of the ERs in all tissues. But even pure antiestrogens appear to fail in this regard with some genes that are regulated by $\mathrm{E}_{2}[32,33]$. ICI 182,780 , the most studied pure antiestrogen, can bind to membrane receptors of $\mathrm{GnRH}$ producing GT1-7 cells and displace binding of $\mathrm{E}_{2}$ coupled to bovine serum albumin [34], suggesting that its binding to membrane receptors is inhibited, but it is not clear if this influences all $E_{2}$ membrane activity [32]. The Atlantic croaker $\mathrm{G}$ protein-coupled receptor 30 has been shown to function as a membrane-bound estrogen receptor and its function is agonized by ICI 182,780 [35]. Other $E_{2}$ activated pathways may not be inhibited by ICI 182,780 , as has been shown for $E_{2}$-stimulated gene regulation through an SP1 site [33]. ZM interactions with membrane receptors have not been studied. 
Unlike mammalian species, as many as three to four different ERs have been identified in teleost fish [31,36-38] making evaluation of gene regulation by different ER isotypes even more challenging to understand than in mammalian systems. Using in vitro transfection experiments for largemouth bass (Micropterus salmoides) ERs, we have determined that $\mathrm{ZM}$ is equally effective at antagonizing the three soluble receptors [31].

A few studies have investigated the effects of estrogenic mixtures on fish $[20,39,40]$ and the binary mixture of $E_{2}$ with tamoxifen and letrizole, two antiestrogens [41]. However, no studies in fish have investigated the effects of a mixture of EE2 with the potent anti-estrogen, ZM. In this study, the objective was to determine changes in steroidogenesis and in gene expression profiles associated with different exposures by exposing adult male FHM to aqueous doses of $\mathrm{EE}_{2},(2,5,10$ and $50 \mathrm{ng} / \mathrm{L})$; to the pure antiestrogen, $\mathrm{ZM}(100 \mathrm{ng} / \mathrm{L})$; and to mixtures of $\mathrm{EE}_{2}$ and $\mathrm{ZM}$. The hypothesis we tested was that $\mathrm{ZM}$ in the mixture would block the action of $\mathrm{EE}_{2}$ on soluble ERs in the FHM gonad and effectively block gene expression changes observed with $\mathrm{EE}_{2}$ alone.

\section{Results \\ Water Chemistry}

Two distinct experiments were performed. In Exp 1, FHM were treated with three concentrations of $\mathrm{EE}_{2}(2,10$ and

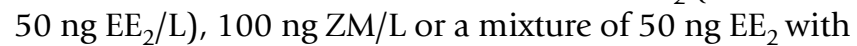
$100 \mathrm{ng} \mathrm{ZM/L}$. In Exp 2, FHM were treated with vehicle, 5

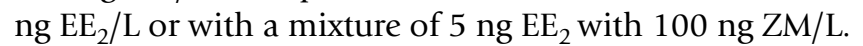
Water concentrations of $\mathrm{EE}_{2}$ alone and in the mixture were close to target values but decreased after $24 \mathrm{~h}$ when they were again renewed to target concentrations (Table 1). Actual concentrations of ZM were not measured.

\section{Biological responses}

There were no mortalities in any of the treatments. Changes in plasma T and VTG were assessed only for a subset of the exposures for $\operatorname{Exp} 1$ ( 10 and $50 \mathrm{ng} \mathrm{EE} / / \mathrm{L}, 100$

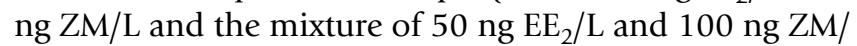
L) and only plasma VTG was assessed for exposures for Exp 2. Within $48 \mathrm{~h}$, plasma T levels in males were dramatically reduced in all treatments that were measured for Exp 1 (Figure 1A). In the same time frame there was a significant increase in plasma VTG for the two $\mathrm{EE}_{2}$ concentra-

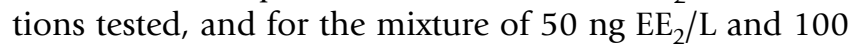
ng ZM/L (Figure 1B). Exposure to $100 \mathrm{ng} \mathrm{ZM} / \mathrm{L}$ alone did not induce VTG. In the second experiment plasma VTG was significantly up-regulated for the $5 \mathrm{ng} \mathrm{EE}_{2} / \mathrm{L}$ and for the mixture of $5 \mathrm{ng} \mathrm{EE}_{2}$ with $100 \mathrm{ng} \mathrm{ZM} / \mathrm{L}$ (Figure 1C).

\section{Microarray Results}

As described in the Methods section, two microarray experiments were performed, one using testis from FHM

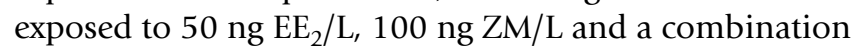

Table I: Chemical analysis of water exposures.

\begin{tabular}{lcccc}
\hline & \multicolumn{5}{c}{ EE2 Conc, ng/La } \\
& Spike & SE & 24 h Post spike & SE \\
\hline Experiment I & & & & \\
TEG & BDLe & & BDL & \\
EE2-2 & 1.16 & 0.12 & 0.23 & 0.03 \\
EE2-10 & 9.02 & 0.59 & 0.13 & 0.05 \\
EE2-50 & 57.92 & 0.61 & 6.84 & 1.43 \\
Mixture EE2-50/ZM-100 & 60.36 & 1.82 & 24.3 & 2.07 \\
& & & & \\
Experiment 2 & & & & \\
TEG & $\mathrm{BDL}$ & & $\mathrm{BDL}$ & \\
EE2-5 & 2.98 & 0.17 & 2.78 & 0.41 \\
Mixture EE2-5/ZM-100 & 3.50 & 0.30 & 0.73 & 0.1 \\
\hline
\end{tabular}

a, Detection limit for the ELISA in $50 \mathrm{ng} / \mathrm{L}$

b, SE, Standard error

c, Concentration of EE2 in tank at the end of $24 \mathrm{~h}$ and before exposure solutions were replaced

d, TEG, triethylene glycol; EE2, I7 $\alpha$-ethinylestradiol; ZM, ZM 189, I54 e, BDL, below detection limit

of both and another using testis from FHM exposed to 5

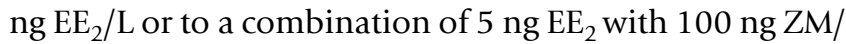
$\mathrm{L}$. The rest of the samples from other $\mathrm{EE}_{2}$ doses were reserved for the quantitative real time PCR (Q-PCR) experiments described below. Samples from the first experiment were analyzed using a 2,000 gene oligonucleotide microarray, and the results are shown in the two sided hierarchical cluster in Figure 2A. The heat map represents genes differentially expressed $(p<0.01)$ between testis of vehicle control and treated fish. We analyzed four biological samples for each of the exposures; each column in Figure 2A represents one of the samples. As expected, control fish clustered together, whereas fish treated with $\mathrm{EE}_{2}$ alone or with a combination of $\mathrm{EE}_{2}$ and $\mathrm{ZM}$ formed a different cluster. Exposure to ZM alone showed the least difference compared to solvent controls; however, even in this comparison there were some differences, suggesting that ZM can influence up- and down-regulation of gene expression in males. There were minor differences between the non-solvent and solvent controls (data not shown).

Exposure to $50 \mathrm{ng} \mathrm{EE}_{2} / \mathrm{L}$ caused many differences in gene expression. The mixture of $100 \mathrm{ng} \mathrm{ZM} / \mathrm{L}$ and $50 \mathrm{ng} \mathrm{EE}_{2} / \mathrm{L}$ reversed the change for several genes affected by $\mathrm{EE}_{2}$ alone, but at this 2:1 ratio the antiestrogen concentration seemed insufficient to totally block the effects of $\mathrm{EE}_{2}$.

Based on these initial results, we conducted a second study, this time using $5 \mathrm{ng} \mathrm{EE}_{2} / \mathrm{L}$ and a mixture of $100 \mathrm{ng}$ $\mathrm{ZM} / \mathrm{L}$ with $5 \mathrm{ng} \mathrm{EE}_{2} / \mathrm{L}$ (a ratio of 20:1; Figure 2B). For this analysis, we used a newer 22,000 gene array that had subsequently become available. Exposure to $5 \mathrm{ng} \mathrm{EE}_{2} / \mathrm{L}$ 
A

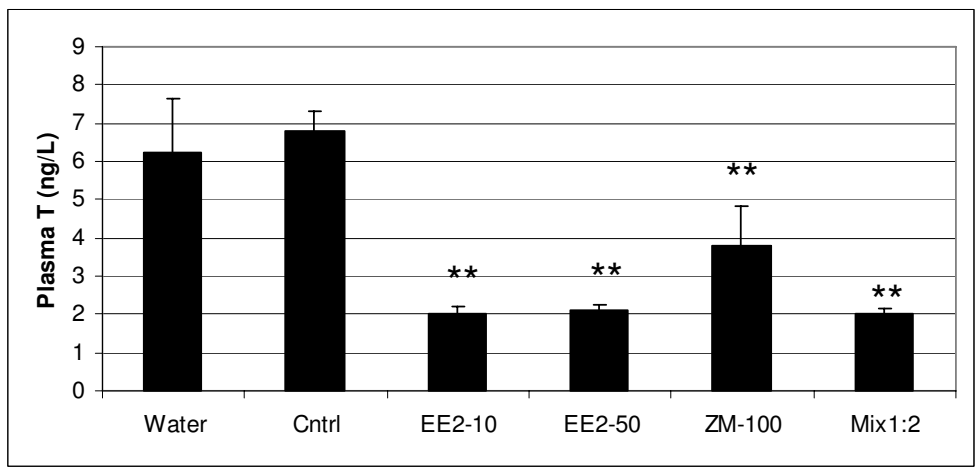

B

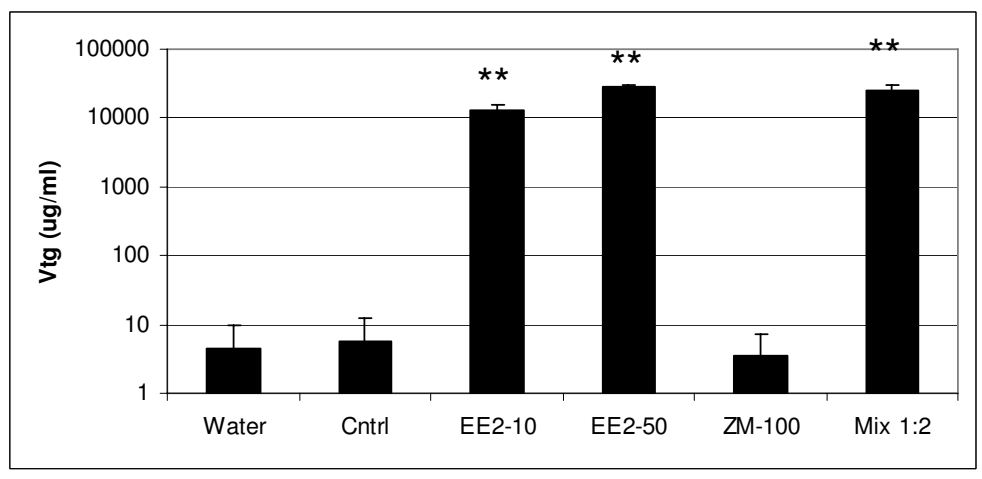

C

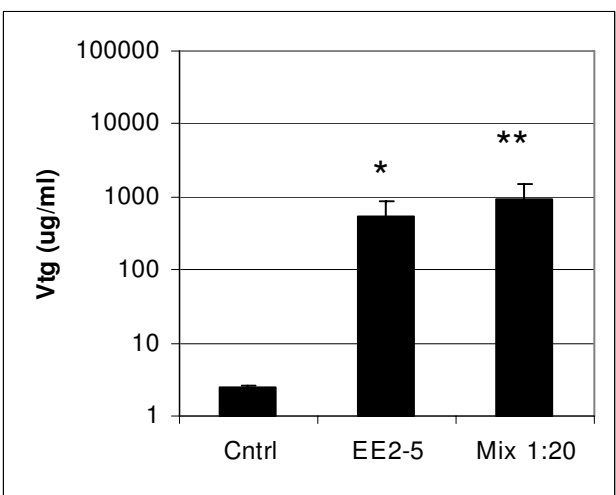

Figure I

Phenotypic anchoring measurements for male fathead minnows. (A and B) Experiment $I$. (A) Plasma T concentrations $(\mathrm{ng} / \mathrm{mL})$, (B) Plasma vitellogenin concentrations $(\mu \mathrm{g} / \mathrm{mL})$ in the same fish samples. (Cntrl) triethylene glycol control, $\left(\mathrm{EE}_{2^{-}}\right.$

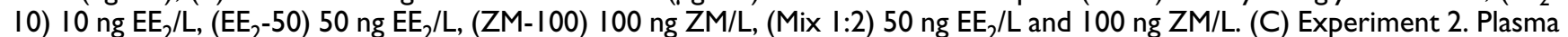
VTG concentrations $(\mu \mathrm{g} / \mathrm{mL})$. ( $\left.\mathrm{EE}_{2}-5\right) 5 \mathrm{ng} \mathrm{EE_{2 }} / \mathrm{L} ;$ (Mix I:20) $5 \mathrm{ng} \mathrm{EE}_{2} / \mathrm{L}$ and $100 \mathrm{ng} Z \mathrm{ZM} / \mathrm{L}$. Significance $* * \mathrm{P} \leq 0.00 \mathrm{I}$ and $* \mathrm{P} \leq 0.05$.

increased plasma VTG (Figure 1C), while the 20-fold excess of $\mathrm{ZM}$ in the mixture did not affect this increase. A group of 173 genes was altered $(p<0.01)$ after exposure

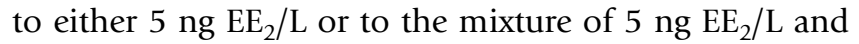
$100 \mathrm{ng} \mathrm{ZM} / \mathrm{L}$ (Figure 3). These changes are plotted in order of their degree of expression change for $\mathrm{EE}_{2}$ (Figure $3 \mathrm{~A}$ ), with 83 genes up-regulated and 90 genes down-regulated. Keeping the same order of genes, their fold-expression is plotted for the mixture (Figure $3 \mathrm{~B}$ ). It is clear from this graph that while $\mathrm{ZM}$ blocks the $\mathrm{EE}_{2}$ effects for some genes, it does not do so for all. There also appears to be a few genes in the middle of this distribution that are significantly altered only by the mixture and not by $\mathrm{EE}_{2}$ alone.

Of the 173 regulated genes, 71 genes were modulated by $\mathrm{EE}_{2}$ and blocked by $\mathrm{ZM}$ (i.e. reduced expression relative to $\mathrm{EE}_{2}$ alone) in the mixture treatment (Figure $4 \mathrm{~A}$ and $4 \mathrm{~B}$ ). These genes are likely directly regulated by one or more of the soluble ERs and include "cellular processes involved in calcium-dependent cell-cell adhesion," "sugar transporters," "gonadal mesoderm development," "protein repair," and "proteolysis and gas transport" (see Additional file 1). Expression of the remaining 102 genes modulated by $\mathrm{EE}_{2}$ was either not affected or was enhanced in either direction by the addition of ZM (Figure 4C and 4D). Many of these genes appear to be involved in signaling cascades, as well as other functions such as "peptide crosslinking," "amino acid biosynthesis and metabolism," "regulation of the immune response," "lipid modification," or "response to stress and to radiation" (see Additional file 2).

\section{Quantitative real-time reverse transcriptase PCR (Q-PCR)} Genes that were tested by Q-PCR (Figure 5) were used to both validate the arrays and to focus on genes whose protein products are involved in steroidogenesis and were 


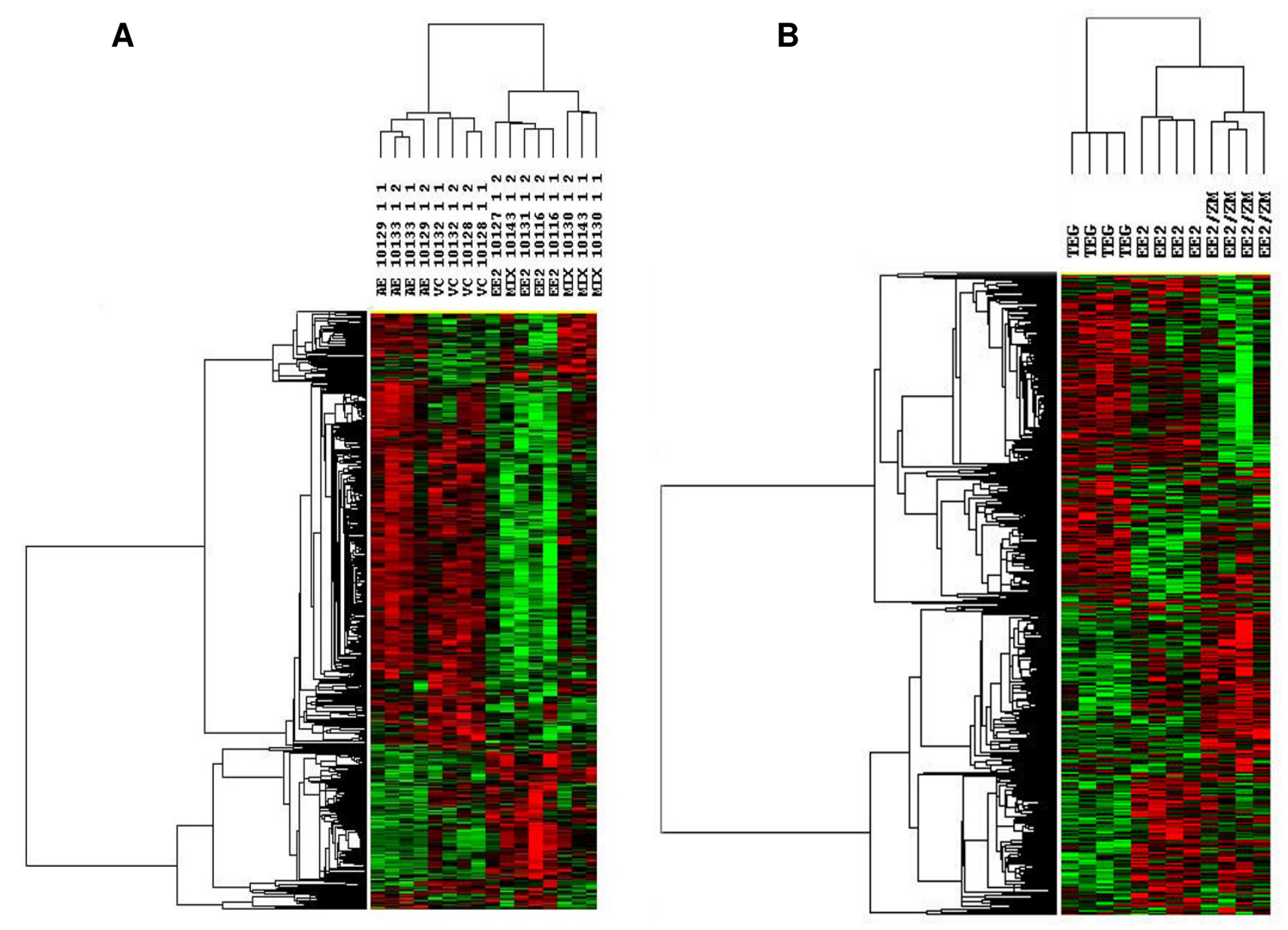

Figure 2

Bi-directional hierarchical cluster analysis of gene expression changes. Green indicates down-regulation relative to control and red indicates up-regulation relative to control. Fathead minnows were exposed to (A) $50 \mathrm{ng} \mathrm{EE}_{2} / \mathrm{L}\left(\mathrm{EE}_{2}\right)$, I00 ng $\mathrm{ZM} / \mathrm{L}(\mathrm{ZM})$, a mixture of $50 \mathrm{ng} \mathrm{EE}_{2} / \mathrm{L}$ and $100 \mathrm{ng} \mathrm{ZM} / \mathrm{L}$ (Mix), or TEG control (Cntrl). Array analysis was on the $2 \mathrm{~K}$ array. (B) $5 \mathrm{ng} \mathrm{EE}_{2} / \mathrm{L}\left(\mathrm{EE}_{2}\right)$, a mixture of $5 \mathrm{ng} \mathrm{EE}_{2} / \mathrm{L}$ with $100 \mathrm{ng} \mathrm{ZM} / \mathrm{L}\left(\mathrm{EE}_{2} / \mathrm{ZM}\right)$ or TEG control (Cntrl). Array analysis was on the $22 \mathrm{~K}$ array. Top, clustering was performed by treatment; side, clustering was performed by gene. Each column represents a different array.

expected to be affected by $\mathrm{EE}_{2}$ [42]. Of the genes tested, steroidogenic acute regulatory protein (StAR), cholesterol side-chain cleavage enzyme (P450scc), cytochrome P450 $17 \alpha$ hydroxylase, 17,20 lyase (CYP17) and inhibin were

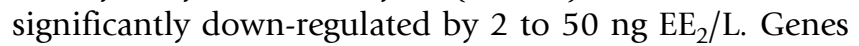
for hydroxysteroid dehydrogenases (HSDs) $3 \beta$-HSD and $11 \beta$-HSD and cytochrome P450 aromatase A-isoform (CYP19A) were not significantly altered, but $11 \beta-H S D$ and CYP19A showed a downward tendency.

\section{Functional Analysis}

While it is interesting to identify individual genes regulated by $\mathrm{EE}_{2}$, most biological processes occur through functional pathways. To assess this, we first assigned as many of the FHM genes as possible to GO categories and to human homologs and then used this information to visualize pathways via Pathway Studio ${ }^{\circledR}$, software from Ariadne Genomics (Rockville, MD, USA). Of the 1,048 genes regulated by any treatment $(p<0.05)$, we were able to assign GO categories to 684 genes (65\%). Of these we were able to assign human homologs to 536 genes (51\% of the original group).

Because of its environmental significance, we focused on the $5 \mathrm{ng} \mathrm{EE}_{2} / \mathrm{L}$ data for $\mathrm{GO}$ analyses. The data set was reduced by statistically determining GO categories for biological processes that were over-represented among the regulated genes which are arranged by increasing $p$-value (up to 0.05 ) in Table 2. Since GO categories are listed in a hierarchical format, we removed higher order categories if a lower category was present. We found 39 GO biological process categories up-regulated and 51 categories down- 
A

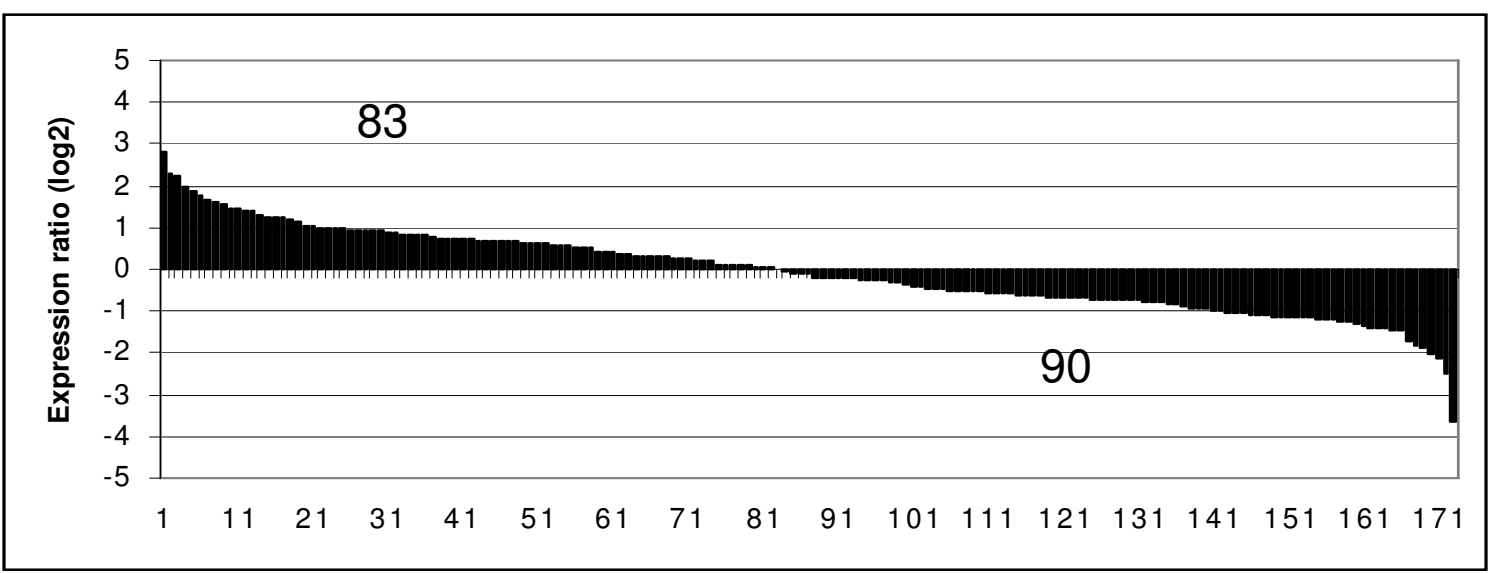

B

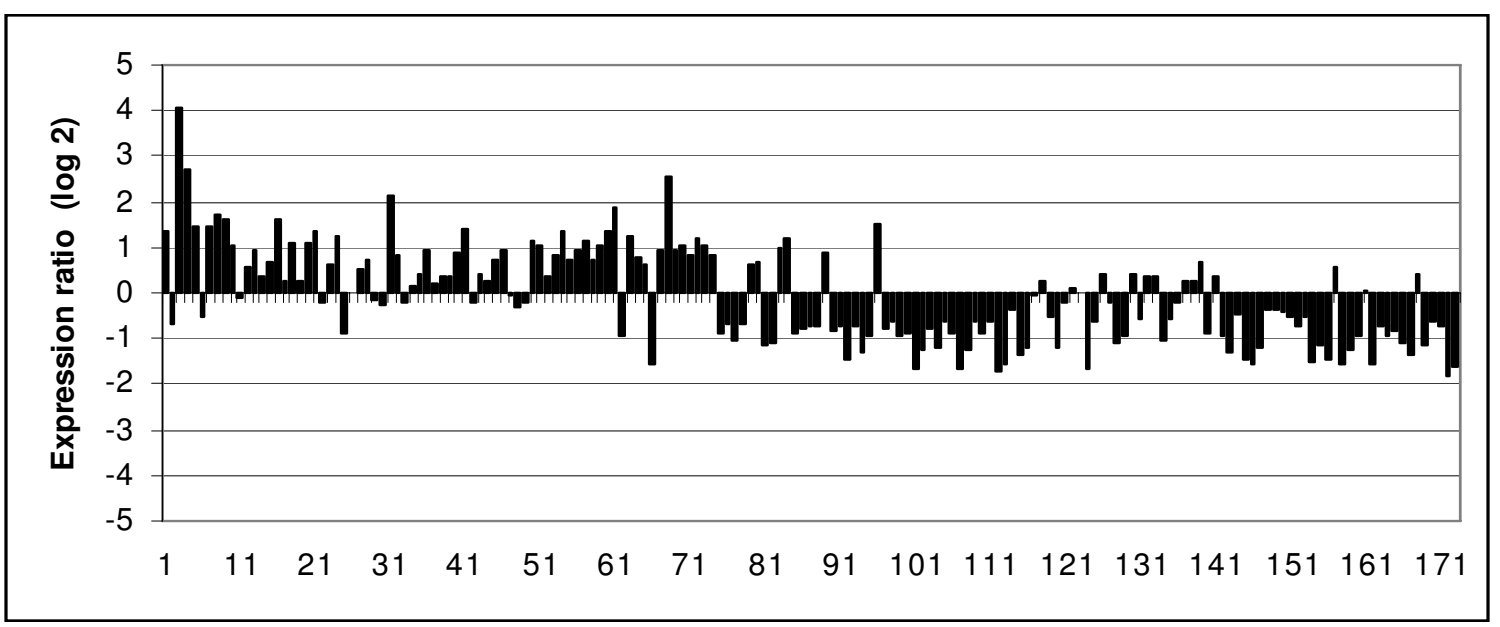

Figure 3

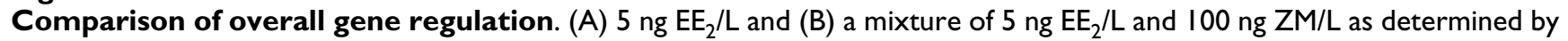
the $22 \mathrm{~K}$ array. The genes were ordered according to their expression level in the $\mathrm{EE}_{2}$ treatment $(p<0.0 \mathrm{I})$ and represent median expression values of the four arrays for each condition.

regulated. The most significantly up-regulated GO category was "development," while "DNA replication," "response to radiation," "mutagenesis," "DNA repair," "response to light stimulus," "response to DNA damage stimulus," "DNA metabolism," and "response to endogenous stimulus" were the most significantly down-regulated categories.

\section{Discussion}

\section{Steroidogenesis}

We chose three test concentrations of $\mathrm{EE}_{2}(2,5$, and $10 \mathrm{ng}$ $\mathrm{EE}_{2} / \mathrm{L}$ ) with known environmental relevance, and one

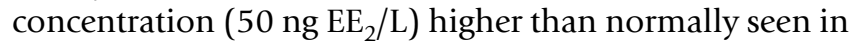
the environment $[43,44]$. In our experiments, 10 and 50

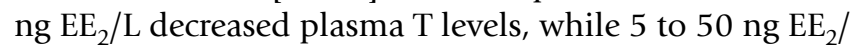
$\mathrm{L}$ increased plasma VTG concentrations in male fish. To our best knowledge, $\mathrm{ZM}$ is not present in the environ- ment, although it represents a potentially important mechanism of action, ER antagonism [45]. The concentration we used, $100 \mathrm{ng} \mathrm{ZM/L}$, and the time of exposure, 48 $\mathrm{h}$, are lower and shorter, respectively than in most other studies [46,47] where ZM has been shown to have effects in fish. We chose $100 \mathrm{ng} \mathrm{ZM} / \mathrm{L}$ to attempt to discern intermediate effects on sensitive genes.

In our study, ZM treatment alone or in the mixture with $\mathrm{EE}_{2}$ decreased plasma $\mathrm{T}$ levels after $48 \mathrm{~h}$ but alone it did not induce plasma VTG concentrations nor did it inhibit the increase in VTG induced by $\mathrm{EE}_{2}$ in the mixture in males. In a study by Panter et al [47] ZM significantly decreased VTG after $4 \mathrm{~d}$ in $\mathrm{E}_{2}$-treated juvenile FHM, but only at a concentration of $76 \mu \mathrm{g} / \mathrm{L}$, a concentration almost 100 -times greater than tested in our experiment. In mummichog (Fundulus heteroclitus), there was decrease of 
A

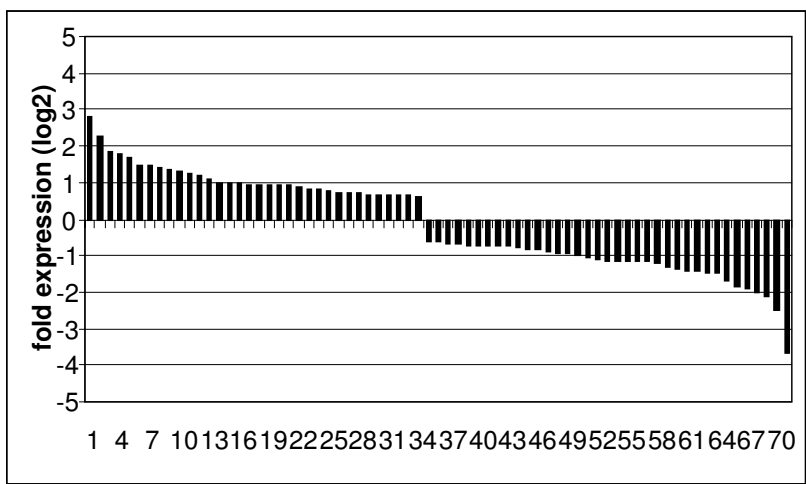

B

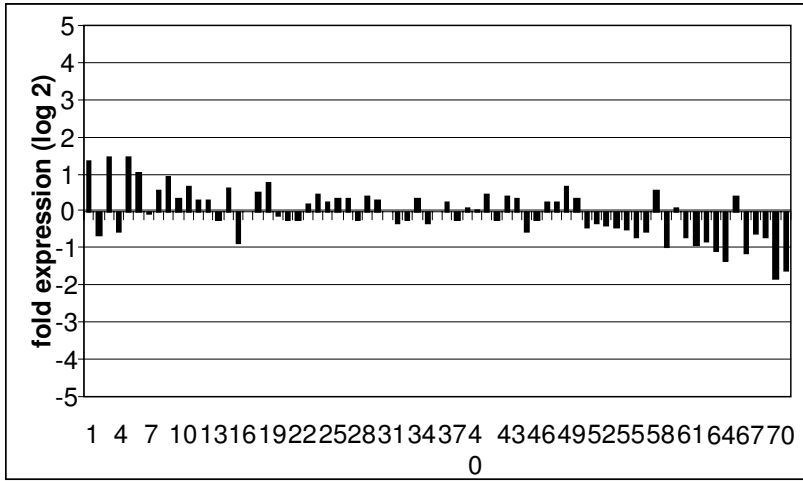

C

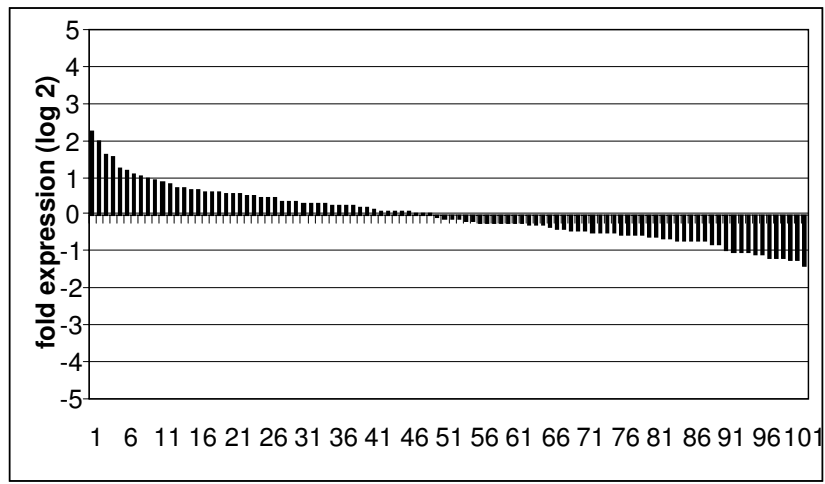

D

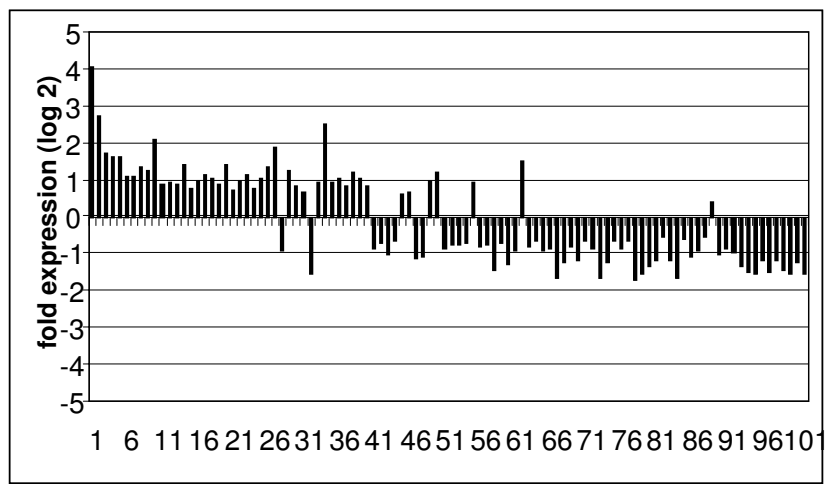

\section{Figure 4}

Competitive and non-competitive blocking of gene expression by ZM. (A) Genes differentially changed by 5 ng $E E_{2} / L$

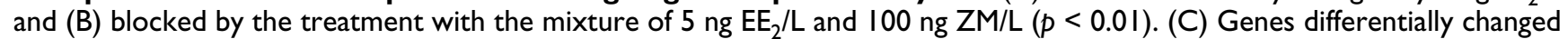
by $5 \mathrm{ng} \mathrm{EE} / \mathrm{L}$ but (D) whose expression was either not changed or enhanced by the treatment with the mixture of $5 \mathrm{ng} E E_{2} / \mathrm{L}$ and $100 \mathrm{ng} Z M / L$. Genes are plotted in order of their change in expression with $\mathrm{EE}_{2}(p<0.0 \mathrm{I})$.

plasma $\mathrm{T}$ levels in males exposed for 7 days to $250 \mathrm{ng} \mathrm{ZM/}$ L but not when treated with $100 \mathrm{ng} \mathrm{ZM/L;} \mathrm{in} \mathrm{those} \mathrm{studies}$ there were no effects on VTG levels in males or females with as much as 1,000 ng ZM/L [46].

The Q-PCR data on mRNAs for specific enzymes involved in the biosynthesis of $\mathrm{T}$ suggest that the depression of plasma T levels may have occurred directly at the level of steroidogenesis, possibly by direct ER-mediated control of promoters. In the case of CYP17, its down-regulation was blocked by ZM (microarray data), suggesting that it may be regulated via ERs.

\section{Pathway Analysis}

Pathway Studio ${ }^{\oplus}[48]$ was used to visualize changes in gene expression from exposure to $5 \mathrm{ng} \mathrm{EE}_{2} / \mathrm{L}$, or to the

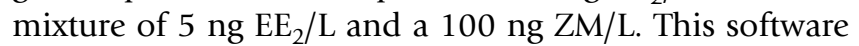
can be used effectively to compare expression changes with the much larger database of human protein interactions, but only if gene identities are converted to their human homologs. Important caveats for this type of analysis are that there may be many fish genes for which there are no human homologs (e.g., VTG), and some genes in fish belonging to gene families conserved in mammals may actually function differently in fish due to chromosomal duplications. Given these caveats, this type of analysis can help visualize interactions among gene products and their localization in cellular compartments and assist in the formulation of hypotheses that can be tested in future research.

An interactome is defined as a set of genes whose protein products are functionally linked together either by direct binding, regulation of activity, regulation of expression, promoter binding, protein modification or molecular transport [48]. Using the databases available in PubMed 
A
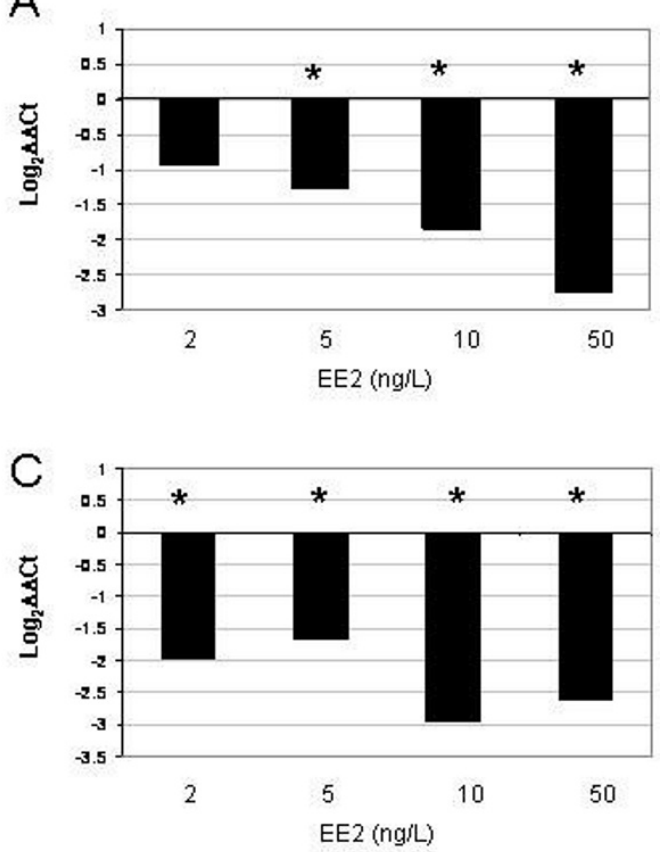

$E$

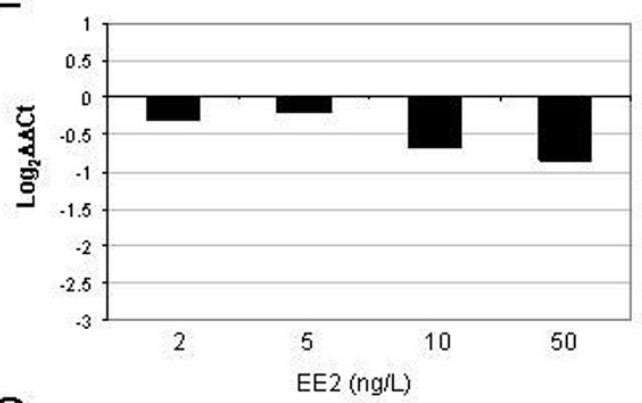

$\mathrm{G}$

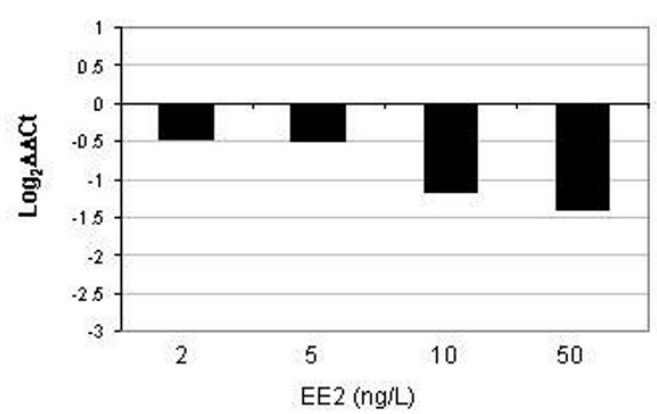

B
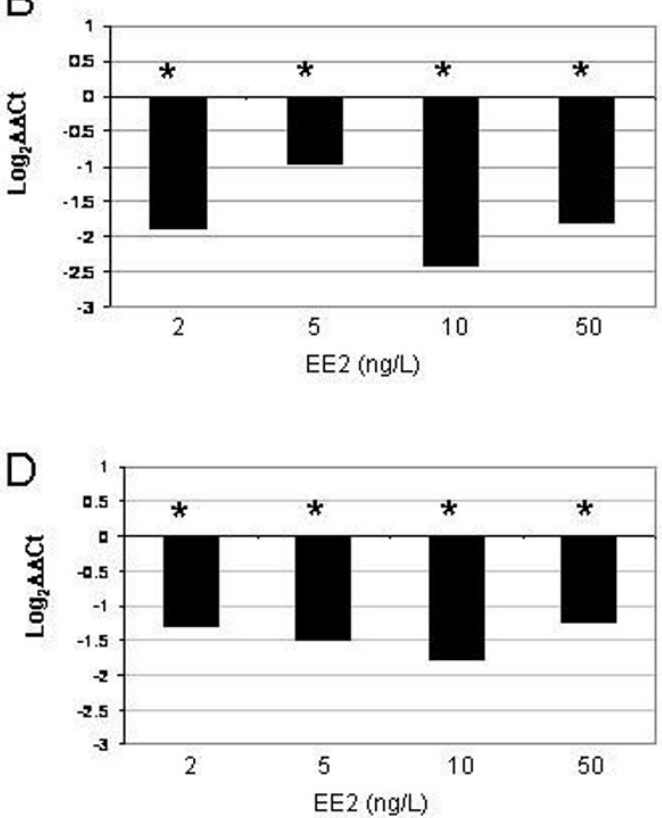

$\mathrm{F}$

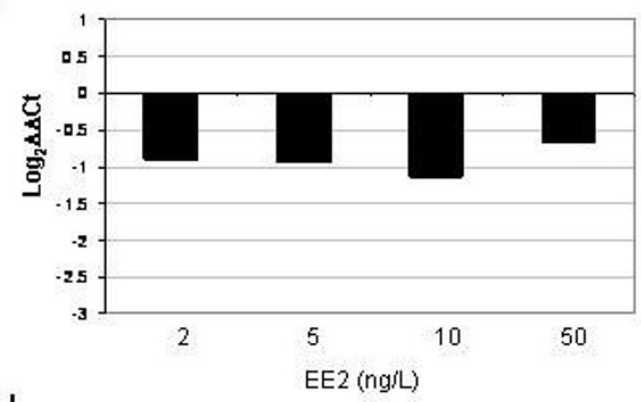

$\mathrm{H}$

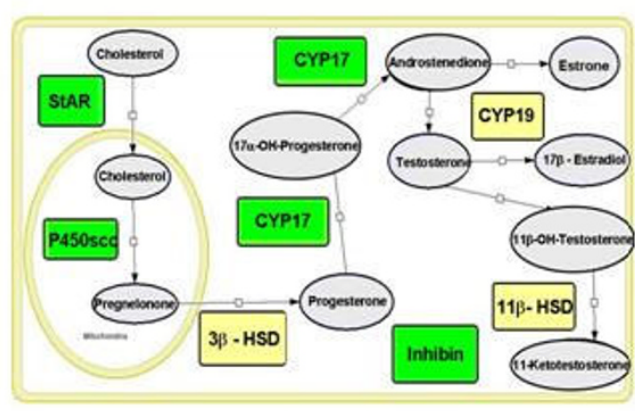

\section{Figure 5}

Q-PCR analysis of mRNAs for proteins involved in steroidogenesis. Q-PCR results are expressed as fold difference compared to control. Panel A, StAR; Panel B, P450scc; Panel C, CYPI7; Panel D, Inhibin; Panel E, CYPI 9; Panel F, 33-HSD; Panel G, I I $\beta$-HSD; Panel H, model for steroidogenesis. Green boxes refer to mRNAs that are significantly decreased by the treatment in accordance with the Q-PCR graphs illustrated within the panels. Yellow boxes refer to mRNAs that are not significantly changed by the treatments. FHM were treated with TEG, 2, 5, 10 or $50 \mathrm{ng} \mathrm{EE} / \mathrm{L}$. StAR, steroidogenic acute regulatory protein, P450scc, Cytochrome P450 side chain cleavage enzyme, CYPI7, Cytochrome P450 17, CYP 19, gonadal aromatase, inhibin, hydroxysteroid dehydrogenases including 3 $\beta$-HSD and I I $\beta$-HSD. 
Table 2: GO biological processes that are regulated by $5 \mathrm{ng} / \mathrm{L} \mathrm{EE}_{2}$

\begin{tabular}{|c|c|c|c|c|}
\hline \multicolumn{5}{|c|}{ UPREGULATED } \\
\hline GO ID & GO Biological Process & Fisher $\mathrm{p}$ Value & \# of Genes Selected & \# of Genes on Array \\
\hline GO:0007275 & development & 4.35E-03 & 36 & 1250 \\
\hline GO:0040036 & regulation of fibroblast growth factor receptor signaling & I.58E-02 & 2 & 9 \\
\hline GO:0016265 & death & I.62E-02 & 3 & 27 \\
\hline GO:0018149 & peptide cross-linking & $1.88 \mathrm{E}-02$ & 2 & 10 \\
\hline GO:0050777 & negative regulation of immune response & I.88E-02 & 2 & 10 \\
\hline GO:0006955 & immune response & I.93E-02 & 10 & 251 \\
\hline GO:0050776 & regulation of immune response & 2.09E-02 & 3 & 30 \\
\hline GO:0050727 & regulation of inflammatory response & 2.19E-02 & 2 & 11 \\
\hline GO:0006694 & steroid biosynthesis & $2.26 \mathrm{E}-02$ & 3 & 31 \\
\hline GO:0006730 & one-carbon compound metabolism & 2.44E-02 & 3 & 32 \\
\hline GO:0008543 & fibroblast growth factor receptor signaling pathway & $2.53 \mathrm{E}-02$ & 2 & 12 \\
\hline GO:0015758 & glucose transport & $2.53 \mathrm{E}-02$ & 2 & 12 \\
\hline GO:0042770 & DNA damage response, signal transduction & $2.53 \mathrm{E}-02$ & 2 & 12 \\
\hline GO:0008645 & hexose transport & $2.88 \mathrm{E}-02$ & 2 & 13 \\
\hline GO:0015749 & monosaccharide transport & $2.88 \mathrm{E}-02$ & 2 & 13 \\
\hline GO:0008284 & positive regulation of cell proliferation & $3.24 \mathrm{E}-02$ & 3 & 36 \\
\hline GO:0019439 & aromatic compound catabolism & $3.26 \mathrm{E}-02$ & 2 & 14 \\
\hline GO:0007I54 & cell communication & $3.56 \mathrm{E}-02$ & 41 & 1692 \\
\hline GO:004328I & regulation of caspase activity & $3.65 \mathrm{E}-02$ & 2 & 15 \\
\hline GO:005I24I & negative regulation of organismal physiological process & $3.65 \mathrm{E}-02$ & 2 & 15 \\
\hline GO:00096II & response to wounding & $3.73 \mathrm{E}-02$ & 7 & 167 \\
\hline GO:0009607 & response to biotic stimulus & $3.91 \mathrm{E}-02$ & 11 & 324 \\
\hline GO:005I707 & response to other organism & 4.03E-02 & 7 & 170 \\
\hline GO:0045596 & negative regulation of cell differentiation & 4.06E-02 & 2 & 16 \\
\hline GO:0009605 & response to external stimulus & 4. $18 \mathrm{E}-02$ & 8 & 209 \\
\hline GO:005I239 & regulation of organismal physiological process & 4.19E-02 & 4 & 69 \\
\hline GO:005I242 & positive regulation of cellular physiological process & $4.48 \mathrm{E}-02$ & 5 & 103 \\
\hline GO:0006952 & defense response & 4.48E-02 & 10 & 291 \\
\hline GO:0019882 & antigen presentation & 4.92E-02 & 2 & 18 \\
\hline
\end{tabular}

\section{DOWNREGULATED}

\section{GO ID GO Name}

Fisher p Value \# of Genes Selected \# of Genes on Array

\begin{tabular}{|c|c|c|c|c|}
\hline GO:0006260 & DNA replication & $9.27 \mathrm{E}-04$ & 9 & 124 \\
\hline GO:00093।4 & response to radiation & I.5IE-03 & 5 & 40 \\
\hline GO:0006280 & mutagenesis & 2.08E-03 & 2 & 2 \\
\hline GO:000628I & DNA repair & 5.33E-03 & 9 & 163 \\
\hline GO:0009416 & response to light stimulus & $5.5 I E-03$ & 4 & 34 \\
\hline GO:0006974 & response to DNA damage stimulus & 7.9IE-03 & 9 & 174 \\
\hline GO:0006259 & DNA metabolism & $8.60 \mathrm{E}-03$ & 17 & 458 \\
\hline GO:0009719 & response to endogenous stimulus & $9.05 \mathrm{E}-03$ & 9 & 178 \\
\hline GO:0006139 & $\begin{array}{l}\text { nucleobase, nucleoside, nucleotide and nucleic acid } \\
\text { metabolism }\end{array}$ & $1.29 \mathrm{E}-02$ & 56 & 2183 \\
\hline GO:0007623 & circadian rhythm & I.74E-02 & 2 & 9 \\
\hline GO:0018149 & peptide cross-linking & 2.07E-02 & 2 & 10 \\
\hline GO:0016339 & calcium-dependent cell-cell adhesion & $2.4 \mathrm{IE}-02$ & 2 & 11 \\
\hline GO:0006885 & regulation of $\mathrm{pH}$ & $2.78 \mathrm{E}-02$ & 2 & 12 \\
\hline GO:000I775 & cell activation & $3.00 \mathrm{E}-02$ & 3 & 33 \\
\hline GO:004532I & immune cell activation & $3.00 \mathrm{E}-02$ & 3 & 33 \\
\hline GO:0006508 & proteolysis & 3.17E-02 & 16 & 493 \\
\hline GO:0000245 & spliceosome assembly & 3.17E-02 & 2 & 13 \\
\hline GO:0046839 & phospholipid dephosphorylation & 3.17E-02 & 2 & 13 \\
\hline GO:0043283 & biopolymer metabolism & $3.56 \mathrm{E}-02$ & 53 & 2167 \\
\hline GO:0007I69 & $\begin{array}{l}\text { transmembrane receptor protein tyrosine kinase signaling } \\
\text { pathway }\end{array}$ & $3.65 \mathrm{E}-02$ & 5 & 92 \\
\hline GO:0007I56 & homophilic cell adhesion & $3.94 \mathrm{E}-02$ & 4 & 64 \\
\hline GO:0006289 & nucleotide-excision repair & $4.00 \mathrm{E}-02$ & 2 & 15 \\
\hline GO:0009266 & response to temperature stimulus & $4.00 \mathrm{E}-02$ & 2 & 15 \\
\hline
\end{tabular}


Table 2: GO biological processes that are regulated by $5 \mathrm{ng} / \mathrm{L} \mathrm{EE}_{2}$ (Continued)

\begin{tabular}{|c|c|c|c|c|}
\hline GO:004247I & ear morphogenesis & $4.00 \mathrm{E}-02$ & 2 & 15 \\
\hline GO:0050896 & response to stimulus & 4.50E-02 & 26 & 948 \\
\hline GO:001994I & modification-dependent protein catabolism & 4.53E-02 & 5 & 98 \\
\hline GO:0043632 & modification-dependent macromolecule catabolism & 4.53E-02 & 5 & 98 \\
\hline GO:0009798 & axis specification & $4.91 \mathrm{E}-02$ & 2 & 17 \\
\hline GO:0030258 & lipid modification & 4.9IE-02 & 2 & 17 \\
\hline GO:0042II0 & $\mathrm{T}$ cell activation & 4.9IE-02 & 2 & 17 \\
\hline
\end{tabular}

at NCBI (National Center for Biotechnology Information, http://www.ncbi.nlm.nih.gov), we have identified interactomes for both the genes that were regulated by $\mathrm{EE}_{2}$ and then blocked by the combination of $\mathrm{EE}_{2}$ and $\mathrm{ZM}$ (Figure $6 \mathrm{~A}$ - called "competitive interactome" in the discussion below), and those that were regulated by $\mathrm{EE}_{2}$ and either not affected by ZM or enhanced (in either direction) by the combination (Figure 6B - called "non-competitive interactome"). We analyzed these separately in order to determine the types of genes that were included in each.

To reduce the complexity of the data, we only examined genes whose products had direct interactions with other entities. We were only able to assign human homologs to about half of the regulated genes, thus our data set underestimates the genes that are directly linked. Entities that showed no linkages to other entities were removed from the figures, but all entities for which we have human homologs are listed in additional files 1 and 2. While it is possible to allow missing entities in the figures in an effort to link all of the entities, this was not attempted because we wanted to exemplify direct interactomes for which there were expression data. Pathway Studio ${ }^{\oplus}$ assigns gene products to cellular compartments depending on their cellular GO terms.

Many of the genes that are found in the "competitive interactome" are known to be regulated by $\mathrm{E}_{2}$ and antagonized by estrogen antagonists such as ICI 182,780 in mammalian systems. These genes fit a classical pattern of regulation via soluble ERs. For some of these genes, there is evidence that they contain EREs in their promoters in mammalian systems. For example, angiotensinogen (AGT) is highly prominent in the example shown (Figure 6A) and serves as a node for the "competitive interactome". AGT is normally secreted from the liver into the blood, but there are reports indicating secretion by other organs as well [49]. Our data suggest that it is also produced by the testis of FHM. AGT helps to control blood pressure and, as illustrated by the large number of interactions in Figure 6A, can interact with other proteins in a complex way. In mammals, AGT contains an ERE in its promoter which is up-regulated by both natural and synthetic estrogenic steroids [50]. Thus, the observation that the $\mathrm{EE}_{2}$-enhanced expression of this gene is blocked by the $\mathrm{EE}_{2}-\mathrm{ZM}$ mixture lends support to the assumption that the competitive interactome includes genes directly regulated by soluble ERs. The other genes in this interactome have also been implicated in $\mathrm{E}_{2}$ signalling in mammalian systems or in cell culture, but there are insufficient data in the literature to determine whether they are all regulated directly by soluble ERs. Furthermore, depending on the tissue the direction of regulation may differ from what we observed in the testis of FHM.

Endothelin receptor type A (EDNRA) is up-regulated by $E_{2}$ during the proliferative phase of the endometrial glandular epithelium [51]. There are no reports on whether or not this up-regulation is through an ERE in the promoter. Different from our results, clusterin (CLU) is down-regulated by $\mathrm{E}_{2}$ in rat endometrium, but this regulation is reversed by tamoxifen, another ER antagonist [52]. CLU is known to be regulated by TGF beta and c-fos through an AP-1 site [53]. CLU is a glycoprotein also known as testosterone-repressed prostate message-2 [54]. This gene is expressed in mammalian testis and apparently has many roles including involvement in apoptosis of the seminal vesicle [55]. Complement component factor $\mathrm{H}$ (Mud1) contains an imperfect palindrome motif in its promoter in L cells that is present in EREs [56], suggesting that this gene could be directly regulated by soluble ERs. Inhibitor of DNA binding 2 (ID2) has been shown to be down regulated by $\mathrm{E}_{2}$ in MCF-7 cells [57] and is directly related to the down-regulation of inhibin alpha, which in turn has a role inhibiting the secretion of FSH from pituitary gonadotrophs [58].

Several genes interconnected with this set were down-regulated by $\mathrm{EE}_{2}$ and blocked by $\mathrm{ZM}$ in our experiment. For example, receptor (calcitonin) activity modifying protein 1 (RAMP1) has been shown to be down-regulated by $\mathrm{E}_{2}$ in rat placenta [59]. Different from our study, some of the down-regulated genes in the FHM testis have been shown to be up-regulated by $E_{2}$ in various mammalian tissues. Pleiotrophin (PTN) is up-regulated in human endometrial epithelial cells [60], and annexin A1 (ANXA1) is upregulated in a lymphoblastic leukemia cell line [61]. Caspase 8 (CASP8) is regulated by activation of human ER $\beta$ but not by ER $\alpha$ [62]. Tissue inhibitor of metalloproteinase 3 (TIMP3) is increased in breast cancer cell growth [63]. It is not clear why the direction of regulation is different in FHM testis, but this may be a tissue specific effect. 
A

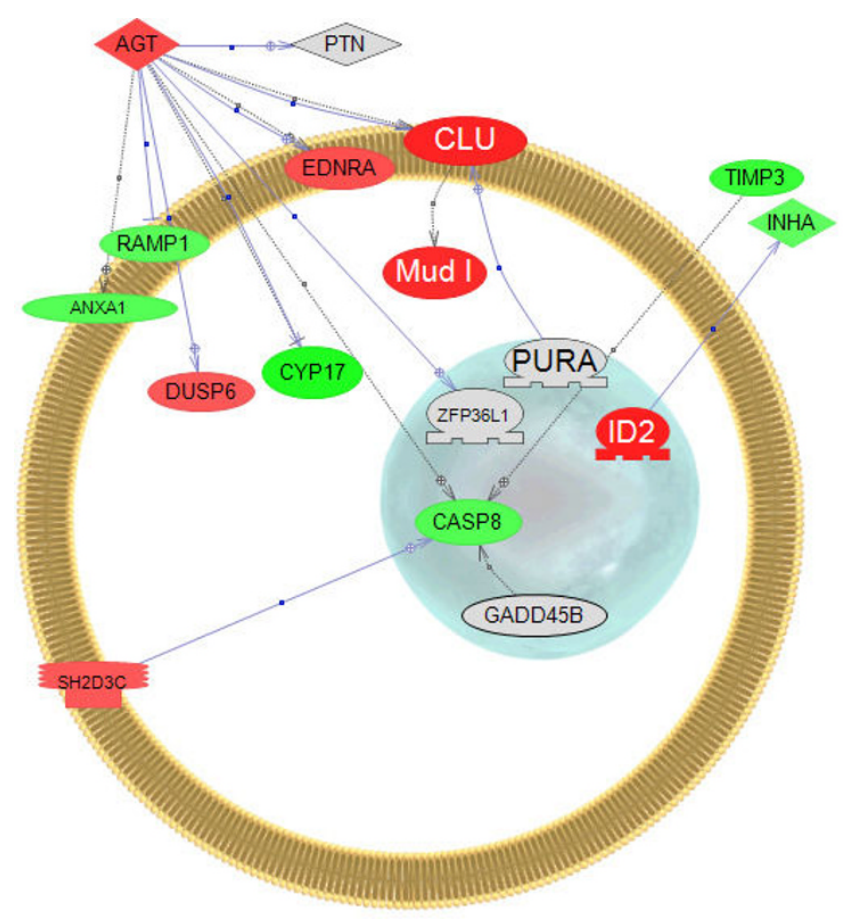

B

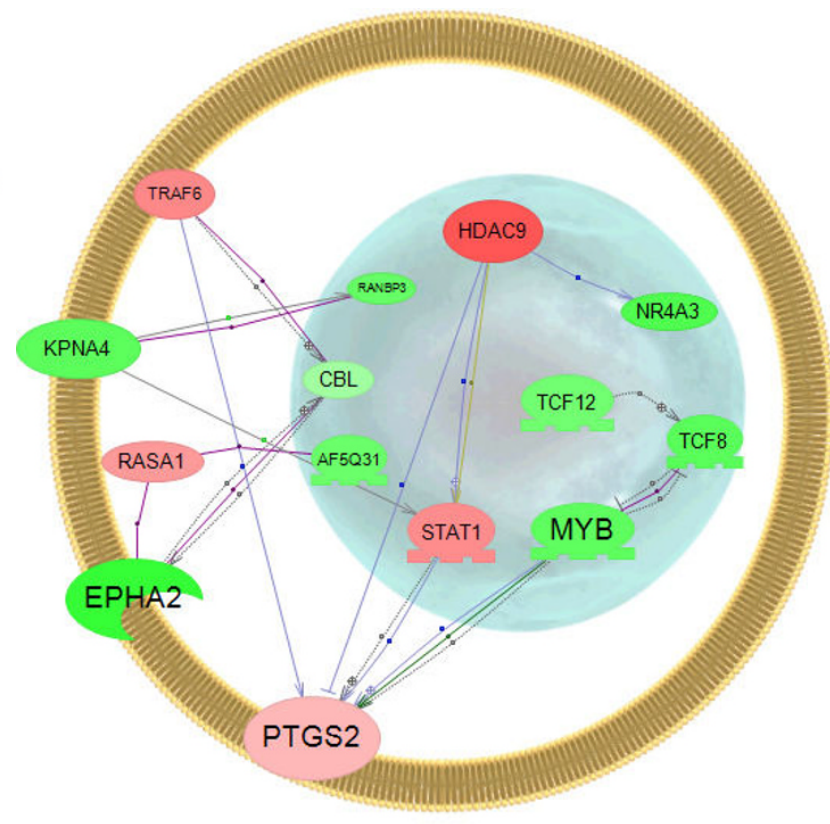

Membrane receptor

Ligand

\section{Figure 6}

Pathway Studio analysis. (A) Competitive interactome consisting of genes that are regulated by $5 \mathrm{ng} \mathrm{EE}_{2} / \mathrm{L}$ and blocked by

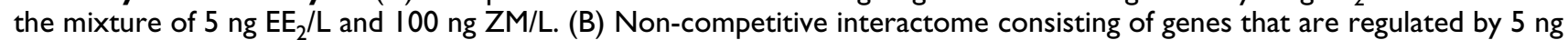
$\mathrm{EE}_{2} / \mathrm{L}$ but either not changed or enhanced by the mixture of $5 \mathrm{ng} \mathrm{EE} / \mathrm{L}$ and $100 \mathrm{ng} Z \mathrm{ZM} / \mathrm{L}$. Red indicates up-regulation, green indicates down-regulation.

In the case of the "non-competitive interactome" (Figure $6 \mathrm{~B})$, the genes were differentially expressed in response to $\mathrm{EE}_{2}$ exposure and either were not affected by $\mathrm{ZM}$ or further amplified by ZM in the mixture. We did not expect to see many genes in this category. This type of effect could be due to activation by $\mathrm{E}_{2}$ on non-canonical response elements, as recently demonstrated in transgenic mice expressing a reporter construct containing SP1 sites [33] or by secondary effects that may have occurred in the $48 \mathrm{~h}$ timeframe. In Figure 6B, we have accentuated one pathway to illustrate this effect. Prostaglandin-endoperoxide synthase 2 (PTGS2) is a central node in this figure and is induced 1.5 fold by $\mathrm{EE}_{2}$ alone but not changed appreciably by the mixture (1.8 fold change). PTGS2 is involved in the synthesis of prostaglandins from arachidonic acid and is influenced by $\mathrm{E}_{2}$ in mammalian tissues [64]. Important in this set of genes is the gene for "signal transducer and activator of transcription 1" (STAT1) which is a critical transcription factor involved in the JAK-STAT signalling pathway central for innate immunity [65] and apoptosis [66], among other functions. This transcription factor is also activated via the retinoic acid receptor signalling pathway [67], thus bridging both the $\mathrm{E}_{2}$ and retinoic acid pathways. Also important is histone deacetylase 9 (HDAC9), a gene product that is involved in chromatin remodelling, allowing access of transcription factors to regions in DNA. No information exists regarding the influence of estrogen on HDAC9 in mammalian tissues but inactivation of other histone deacetlyases is an important step for ER activation in cell lines no longer responsive to $E_{2}[68]$. Tnf receptor-associated factor 6 (TRAF6) is a protein known to be involved in signal transduction through membrane receptors [69], and RAS p21 protein activator 1 appears to play a role in Ras GTPase mediated signal transduction [70]. 
Table 3: Real time PCR primers

\begin{tabular}{lll}
\hline GENE & FWD PRIMER (5' - 3') & REV PRIMER (5' - 3') \\
\hline CYP I7 & ACACAAGGTGGATTACAGTGATAACGT & CTGCGTTTGGCCCTCAGA \\
$3 \beta$-HSD & ATGAGATGCCCTACCCAAAGAC & CCCTTTACCTTTGTGCCATTG \\
II $\beta-$ HSD & GCATCGGCGAGCAGTTG & CTCCTCGCCGTGATAACGA \\
INHB & ACCACGCTACTCGGGATCAA & CGGAGGGACTTCATGCTCTCT \\
CYPI9A & TGCTGACACATGCAGAAAAACTC & CAGCTCTCCGTGGCTCTGA \\
P450sCC & CGACACCCGGACTTGCA & CACGTCTCCTTTAGAGGTGATACG \\
StAR & CTTGAACAGCAAACAGATGACCTT & CTCCCCCATTTGTTCCATGT \\
\hline
\end{tabular}

Among the down-regulated genes were several transcription factors, including transcription factor 12 (TCF12) involved in control of immunoglobulin transcription [71], transcription factor 8 (TCF8), a negative regulator of cadherin [72], myeloblastosis oncogene (MYB), known to be involved in estrogen signalling in some breast cancer cells [73] and AF4/FMR2 family, member 4 (AF5Q31), which functions as a transcriptional regulator in testicular somatic cells, essential for male germ cell differentiation and survival [74]. Karyopherin (importin) alpha 4 (KPNA4) helps import proteins into the nucleus during spermatogenesis [75]. RAN binding protein 3 isoform b (RANBP3) links the RAS and PI3-kinase signaling pathways with nuclear transport [76] and Eph receptor A2 (EPHA2), is a protein in the tyrosine kinase family [77]. The roles of other genes in this interactome are listed in additional file 2 .

It is not clear at this time why so many genes have escaped antagonism by ZM in the mixture exposure. It is possible that they are activated via non-canonical ER interactions with other transcription factors [33] or are the results of activation through $G$ protein-coupled receptor 30 (GPR30), a membrane-bound estrogen receptor [35]. A large percentage of genes in the non-competitive interactome function in non-genomic signaling pathways, raising the possibility that these genes are all regulated via membrane receptors which escape antagonism. Further work will be required to sort out exactly how each of these genes is regulated.

\section{Conclusion}

We used genomics to try to elucidate the mechanisms of action of estrogenic and anti-estrogenic compounds and their potential effects on aquatic organisms. Our data provides some insight into the estrogen-regulated effects, suggesting that response to estrogens occurs via different mechanisms. The use of an estrogen/antiestrogen mixture provides a distinction among different modes of action of estrogenic compounds: through canonical binding to soluble ERs; membrane ERs; or some other potential mechanisms that may not be blocked by pure antiestrogens.

\section{Methods}

Fish Exposure and Tissue Collection

Reproductively-mature, pond-reared FHM were purchased from Andersen Minnow Farm, AR, 4 days prior to starting the experiment. Upon arrival, the fish were treated for parasites and bacteria by a prophylactic salt-water dip $(3 \%, 1 \mathrm{~min})$. Males were separated from the population the following day, and acclimated in the treatment aquaria for $48 \mathrm{~h}$. The water used for this study was carbonfiltered, dechlorinated tap water.

The exposure system consisted of 40 L glass aquaria. Each exposure was conducted in quadruplicate and each aquarium contained eight male FHM in $25 \mathrm{~L}$ of treatment water. Test chemicals for each treatment group (100 L for 4 aquaria) were prepared in separate (by treatment) $250 \mathrm{~L}$ fiberglass tanks the day of exposure. Aquaria were equilibrated with test chemicals for $24 \mathrm{~h}$ prior to the introduction of fish. Test solutions were renewed to $90 \%$ of the 25 L exposure volume after $24 \mathrm{~h}$ and the exposure was ended at $48 \mathrm{~h}$. The positions of the treatment tanks were randomized and test initiation times were staggered to ensure an exposure/sampling interval of $48 \mathrm{~h}$. The fish were not fed the day before and during the experiment. Temperature was maintained at $25^{\circ} \mathrm{C}$ with a photoperiod of $16 \mathrm{~h}$ light: 8 h dark.

\section{Exposure Solutions}

$\mathrm{EE}_{2}$ was purchased from Sigma Chemical Company (St. Louis, MO). ZM189,154 was a generous gift from AstraZeneca. Working solutions for each test chemical consisted of $1 \mathrm{mg} / \mathrm{ml}$ test compound in $70 \%$ triethylene glycol (TEG) and 28.5\% ethanol. This working solution was further diluted to make stock solutions for each treatment (nominal concentrations of 2, 5, 10 and $50 \mathrm{ng} \mathrm{EE} /$

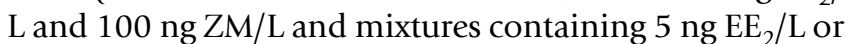

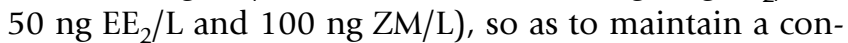
centration of $50 \mu \mathrm{lTEG} / \mathrm{L}$ of test water. $\mathrm{EE}_{2}$ concentrations spanned the environmentally relevant levels (2-10 ng $\mathrm{EE}_{2} / \mathrm{L}$ ) to a concentration higher than would typically occur in the environment. The antiestrogen ZM concentration was chosen to be higher than $\mathrm{EE}_{2}$ so that it could 
effectively block action on the ERs. The concentration of $\mathrm{ZM}$ in the two mixtures was $100 \mathrm{ng} \mathrm{ZM} / \mathrm{L}$.

Water samples were collected at the start of the exposures $(0 \mathrm{hr})$, and after $24 \mathrm{~h}$ (both before and after change of tank water) and after $48 \mathrm{~h}$. A sample of the test solution (1 L) was collected in an amber glass bottle with a teflon cap and stored at $4{ }^{\circ} \mathrm{C}$. The water was passed through an AccuBond II ODS-C18 solid phase extraction column (Agilent, Palo Alto, CA) and the $\mathrm{EE}_{2}$ was eluted with $5 \mathrm{ml}$ dichloromethane. After drying, the $\mathrm{EE}_{2}$ residue was reconstituted in $1 \mathrm{ml}$ of buffer and analyzed using an enzymelinked immunosorbent assay (ELISA) kit (Abraxis, Los Angeles, CA), following the manufacturer's instructions. The detection limit for this assay is $50 \mathrm{ng} \mathrm{EE}_{2} / \mathrm{L}$ in the reconstituted solution. We were not able to determine actual concentrations of $\mathrm{ZM}$, so we report only nominal concentrations.

All procedures involving live fish were reviewed and approved by the University of Florida Institutional Animal Care and Use Committee (IACUC). At the conclusion of the exposures, fish were anesthetized (MS-222), weighed to the nearest $0.1 \mathrm{~g}$ and blood samples were collected from the caudal vasculature for analysis of VTG and $\mathrm{T}$ concentrations, as described below. The testes were removed and cut into small pieces. Dissected tissues were flash frozen using liquid nitrogen and stored at $-80^{\circ} \mathrm{C}$ until needed.

\section{Vitellogenin Assay}

Plasma concentrations of VTG were determined by ELISA using a monoclonal antibody, 2D3, previously validated for the FHM [78]. The limit of detection for the FHM VTG ELISA in plasma was $0.5 \mu \mathrm{g} / \mathrm{mL}$. All assays were performed in triplicate and reported as the mean of the three measurements. The coefficient of variation was $<10 \%$ for all samples analyzed. Inter and intra-assay variability was routinely measured by analyzing positive controls on several plates and found to be $<10 \%$ and $<5 \%$, respectively.

\section{Testosterone Radioimmunoassay}

Plasma concentrations of $\mathrm{T}$ were measured using a radioimmunoassay (RIA) validated for the FHM based on a slight modification of a previously published protocol [79]. The antibody against T, 20-TR05, was purchased from Fitzgerald Industries International, Concord, MA. Tritiated label $\left(\left[1,2,6,7-{ }^{3} \mathrm{H}\right] \mathrm{T}\right)$ was from GE Healthcare (Piscataway, NJ). The T standard (Sigma T-1500) was obtained from Sigma Chemical Company (St. Louis, $\mathrm{MO}$ ). Plasma samples (12 $\mu \mathrm{L}$ each) were extracted with 2 $\mathrm{mL}$ of ethyl ether, as described previously [79]. The extraction efficiency was $93 \%$. Samples were analyzed in duplicate. The intraassay coefficients of variance were generally $\varsigma \%$ and all samples were run in one assay to prevent interassay variability.

\section{Data analysis}

Plasma concentrations of $\mathrm{T}$ were analyzed by one-way ANOVA, followed by Fisher Protected Least Significant Difference (PLSD) test for post-hoc analysis. All analyses were carried out using StatView 5.0 (SAS Institute, Inc., Cary, NC). Homoscedasticity was assessed using F - tests, and, where necessary ( $\mathrm{p}<0.05)$, data were log transformed [80]. All data are reported as nontransformed values, as mean \pm SEM, and significance was determined at $p$ value $<0.05$. Plasma VTG concentrations were analyzed by Dunnett's pairwise multiple comparisons on log transformed data.

\section{RNA Extraction}

Total RNA was isolated from $30-50 \mathrm{mg}$ FHM gonadal tissue with the RNA Stat-60 reagent (Tel-test, Friendswood, TX), as previously described [81]. Total RNA was treated with DNase and the quality assessed with an Agilent 2100 BioAnalyzer (Agilent, Palo Alto, CA), and the quantity determined on a NanoDrop spectrophotometer (NanoDrop Technologies, Wilmington, DE). RNA was stored at $-80^{\circ} \mathrm{C}$ until further use.

\section{Microarrays}

Fathead minnow microarrays manufactured by Agilent (Palo Alto, CA) were purchased from EcoArray (Alachua, FL). For the first experiment we used a targeted 2,000 gene array (GPL6516) while for the other we employed a 22,000 gene array $(4 \times 44 \mathrm{~K}$ format, GPL7282). Array hybridizations were performed using a reference design. The reference material, which was used for all studies, consisted of equal amounts of RNA from both female and male tissues (liver, brain and gonad). Four replicates consisting of four different individuals were analyzed for each of the treatments (solvent (TEG) control, non-solvent control, $\left.\mathrm{EE}_{2}, \mathrm{ZM}, \mathrm{EE}_{2} / \mathrm{ZM}\right)$. The cDNA synthesis, cRNA labeling and hybridization were performed following the manufacturer's kits and protocols (Agilent Low RNA Input Fluorescent Linear Amplification Kit and Agilent 60-mer oligo microarray processing protocol; Agilent, Palo Alto, $\mathrm{CA}$ ). The gonad samples were labeled with $\mathrm{Cy}_{5}$ while the reference sample was labeled with $\mathrm{Cy}_{3}$. Once the labeling was complete, samples were hybridized to the microarray using conditions recommended by the manufacturer. After hybridizing for $17 \mathrm{~h}$, microarrays were washed and then scanned with a laser-based detection system (Agilent, Palo Alto, CA). Text versions of the Agilent raw data have been deposited at the Gene Expression Omnibus website (GEO: http://www.ncbi.nlm.nih.gov/geo/; Accession series record number GSE14235).

\section{Bioinformatics}

Microarray image processing and data pre-processing were performed using Agilent's Feature Extraction software v 9.5 (Agilent, 2007). The intensity of each spot was summarized by the median pixel intensity. A $\log _{2}$ trans- 
formed signal ratio between the experimental channel and the reference channel was calculated for each spot, followed by within-array LOWESS transformation and between array scale normalization on median intensities [82].

Two-way ANOVA was performed on $\log _{2}$ transformed signal ratios of each probe individually, followed by TukeyHSD pair-wise comparisons to determine genes whose expression was significantly regulated by the treatments. A $p$-value $\leq 0.05$ was used as the cutoff. Genes whose fold expression changes were less than 1.5 fold were eliminated from further analyses irrespective of statistical significance.

GeneOntology (GO) annotations were provided by EcoArray Inc. based largely on homologies between FHM genes and human genes. Overrepresentation of differentially expressed genes in the biological process GO category was determined by Fisher Exact Test with a $p$-value $\leq$ 0.05 as a cutoff, and the false discovery rate was determined [83]. PathwayStudio ${ }^{\circledast}$ software [48] from Ariadne Genomics (Rockville, MD) was used to determine the list of common regulators among the genes that were differentially expressed in the experiments.

\section{Real-time Polymerase Chain Reaction (Q-PCR)}

Total RNA $(1 \mu \mathrm{g})$ was reverse transcribed into cDNA using $3 \mu \mathrm{l}$ random primers $(0.1 \mu \mathrm{g} / \mu \mathrm{l}), 0.8 \mu \mathrm{ldNTP} \operatorname{mix}(25 \mathrm{mM}$ each dNTP), $2 \mu$ l transcription buffer $(10 \times), 1 \mu \mathrm{l}$ StrataScript RT ( $50 \mathrm{U} / \mu \mathrm{l})$, and $0.5 \mu \mathrm{l}$ RNAse Block (40 U/ $\mu \mathrm{l}$ ) in a final volume of $20 \mu \mathrm{l}$ (all reverse transcription reagents were from Stratagene, La Jolla, CA). The resulting cDNA was used as a template for Q-PCR. Specific primers for selected genes were designed to perform Q-PCR (Table $3)$.

Each Q-PCR reaction consisted of $1 \times$ iQ SYBR Green Supermix (Bio-Rad, Hercules, CA), $0.4 \mu \mathrm{M}$ primers and 1 $\mu \mathrm{l}$ of cDNA in a $25 \mu \mathrm{l}$ reaction. The Q-PCR conditions were $95^{\circ} \mathrm{C}$ for $3 \mathrm{~min}$ and 40 cycles at $95^{\circ} \mathrm{C}$ for $15 \mathrm{sec}$ and $60^{\circ} \mathrm{C}$ for $1 \mathrm{~min}$ in an iCycler Thermal Cycler (Bio-Rad, Hercules, CA). The Q-PCR results were normalized to $18 \mathrm{~S}$ rRNA (Applied Biosystems, Foster City, CA) and analyzed using the $\Delta \Delta \mathrm{Ct}$ method, compared to the vehicle controls. We measured the following mRNAs: cytochrome P450 $17 \alpha$ hydroxylase, 17,20 lyase (CYP17) [84], steroidogenic acute regulatory protein (StAR) [85], cholesterol sidechain cleavage enzyme (P450scc) [85], hydroxysteroid

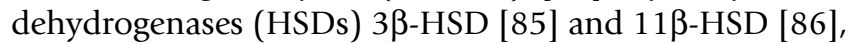
inhibin (INHB) and cytochrome $\mathrm{P} 450$ aromatase A-isoform (CYP19A) [87].

\section{List of abbreviations}

AF5Q31: AF4/FMR2 family, member 4; AGT: angiotensinogen; ANXA1: annexin A1; AP-1: activating pro- tein 1 ; $3 \beta$-HSD: 3 beta hydroxysteroid dehydrogenase; 11ß-HSD: 11 beta hydroxysteroid dehydrogenase; CASP8: caspase 8; CBL: CBL E3 ubiquitin protein ligase; CLU: clusterin; Cntrl: control; CYP 17: cytochrome P450, family 17 , subfamily a, polypeptide 1; CYP19A: cytochrome P450 aromatase A-isoform; DUSP6: dual specific phosphatase 6; EDCs: Endocrine disrupting chemicals; $\mathrm{E}_{2}: 17 \beta$ estradiol; $\mathrm{EE}_{2}: 17 \alpha$ ethinylestradiol; ELISA: enzyme-linked immunosorbent assay; ENDRA: endothelin receptor type A; EPHA2: Eph receptor A2; ER: estrogen receptor; FHM: fathead minnow; GADD45B: growth arrest and DNAdamage-inducible 45 beta; GO: gene ontology; HDAC9: histone deacetylase 9; ID2: inhibitor of DNA binding 2; INHA: inhibin alpha; KPNA4: karyopherin (importin) alpha 4; MYB: myeloblastosis oncogene; Mud 1: complement component factor $\mathrm{H}$; NR4A3: nuclear receptor subfamily 4, group A, member 3; Q-PCR: quantitative real time reverse transcriptase polymerase chain reaction; P450scc: Cytochrome P450 side chain cleavage enzyme; PTGS2: prostaglandin-endoperoxide synthase 2; PTN: pleiotrophin; PURA: purine rich element binding protein A; RAMP1: receptor (calcitonin) activity modifying protein 1; RANBP3: RAN binding protein 3 isoform; RASA1: RAS p21 protein activator 1; RIA: radioimmunoassay; SH2D3C: SH2 domain containing 3C; Sp1: stimulatory protein 1; StAR: steroidogenic acute regulatory protein; STAT1: signal transducer and activator of transcription 1; T: testosterone; TCF8: transcription factor 8; TCF12: transcription factor 12; TIMP3: tissue inhibitor of metalloproteinase 3; TRAF6: Tnf receptor-associated factor 6; VTG: vitellogenin; ZFP36L1: zinc finger protein 36, C3H typelike 1; ZM: ZM 189,154.

\section{Authors' contributions}

NGR, NDD, KHW, MSS and EFO, conceived of the study and helped draft the manuscript; NGR, DLV, EFO, and $\mathrm{KJK}$, performed the experimental work; $\mathrm{LL}$, performed bioinformatics analysis; EJP, GTA, revised the manuscript critically for important intellectual content. All authors read and approved the final manuscript.

\section{Additional material}

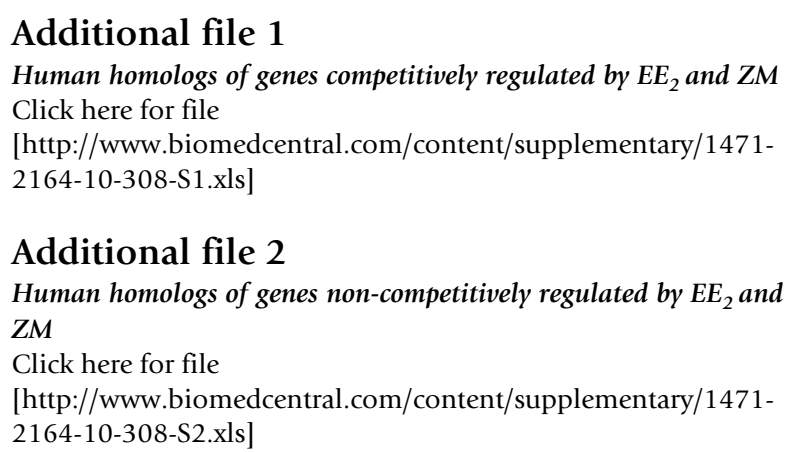




\section{Acknowledgements}

This work was supported by the Environmental Protection Agency STAR grant, (R83 I848) to ND, MS, EO and KW, and by a fellowship from the Spanish Ministry of Sciences and Technology (EX-2004-0986) co-funded by the European Union to NGR. We wish to thank Dr. Thomas Hutchinson, (formerly of AstraZeneca) for the generous gift of ZMI89, I54. The research described in this article does not necessarily reflect the views of the EPA and no official endorsement should be inferred. NDD holds equity in EcoArray, Inc., a company commercializing the microarray technology used in this study.

\section{References}

I. Sumpter JP: Endocrine disrupters in the aquatic environment: An overview. Acta Hydrochimica et Hydrobiologica 2005, 33:9-16.

2. Damstra T, Barlow S, Bergman A, Kavlock RJ, Kraak G Van der: Global Assessment of the State-of-the-Science of Endocrine Disruptors. International Programme on Chemical Safety, World Health Organization: 2002; Geneva, Switzerland 2002: 180.

3. Pickering AD, Sumpter JP: Comprehending endocrine disrupters in aquatic environments. Environmental Science \& Technology 2003, 37( I7):33IA-336A.

4. Jobling S, Nolan M, Tyler CR, Brighty G, Sumpter JP: Widespread sexual disruption in wild fish. Environmental Science \& Technology 1998, 32(17):2498-2506.

5. Folmar LC, Denslow ND, Rao V, Chow M, Crain DA, Enblom J, Marcino J, Guillette $L$ J Jr: Vitellogenin induction and reduced serum testosterone concentrations in feral male carp (Cyprinus carpio) captured near a major metropolitan sewage treatment plant. Environ Health Perspect 1996, 104(10): I096-I I0I.

6. Thorpe KL, Cummings RI, Hutchinson TH, Scholze M, Brighty G, Sumpter JP, Tyler CR: Relative potencies and combination effects of steroidal estrogens in fish. Environ Sci Technol 2003, 37(6): I | 142-I| 49.

7. Ericson JF, Laenge R, Sullivan DE: Comment on "Pharmaceuticals, Hormones, and Other Organic Wastewater Contaminants in U.S. Streams, 1999-2000: A National Reconnaissance. Environmental Science and Technology 2002, 36( 18):4005-4006.

8. Ankley GT, Brooks BW, Huggett DB, Sumpter JP: Repeating history: Pharmaceuticals in the environment. Environmental Science \& Technology 2007, 4 I (24):821 I-82 I7.

9. Kolpin DW, Furlong ET, Meyer MT, Thurman EM, Zaugg SD, Barber LB, Buxton HT: Pharmaceuticals, hormones, and other organic wastewater contaminants in U.S. streams, 19992000: A national reconnaissance. Environ Sci Technol 2002, 36(6): $1202-1211$.

10. Pawlowski S, van Aerle R, Tyler CR, Braunbeck T: Effects of 17alpha-ethinylestradiol in a fathead minnow (Pimephales promelas) gonadal recrudescence assay. Ecotoxicol Environ Saf 2004, 57(3):330-345.

II. Fenske M, Maack G, Schafers C, Segner H: An environmentally relevant concentration of estrogen induces arrest of male gonad development in zebrafish, Danio rerio. Environ Toxicol Chem 2005, 24(5): 1088-1098.

12. Lange R, Hutchinson TH, Croudace $C P$, Siegmund $F$, Schweinfurth $H$, Hampe P, Panter GH, Sumpter JP: Effects of the synthetic estrogen 17 alpha-ethinylestradiol on the life-cycle of the fathead minnow (Pimephales promelas). Environ Toxicol Chem 200I, 20(6):1216-1227.

13. Santos EM, Paull GC, Van Look KJW, Workman VL, Holt WV, Van Aerle R, Kille P, Tyler CR: Gonadal transcriptome responses and physiological consequences of exposure to oestrogen in breeding zebrafish (Danio rerio). Aquatic Toxicology 2007, 83(2): |34-| 42.

14. Parrott JL, Blunt BR: Life-cycle exposure of fathead minnows (Pimephales promelas) to an ethinylestradiol concentration below I ng/L reduces egg fertilization success and demasculinizes males. Environ Toxicol 2005, 20(2): |3|-|4|.

15. Martyniuk C], Xiong H, Crump K, Chiu S, Sardana R, Nadler A, Gerrie $E R$, Xia $X$, Trudeau VL: Gene expression profiling in the neuroendocrine brain of male goldfish (Carassius auratus) exposed to I7alpha-ethinylestradiol. Physiol Genomics 2006, 27(3):328-336.
16. Andersen L, Holbech H, Gessbo A, Norrgren L, Petersen GI: Effects of exposure to 17alpha-ethinylestradiol during early development on sexual differentiation and induction of vitellogenin in zebrafish (Danio rerio). Comp Biochem Physiol C Toxicol Pharmacol 2003, I34(3):365-374

17. Weber LP, Balch GC, Metcalfe CD, Janz DM: Increased kidney, liver, and testicular cell death after chronic exposure to 17alpha-ethinylestradiol in medaka (Oryzias latipes). Environ Toxicol Chem 2004, 23(3):792-797.

18. Miller DH, Jensen KM, Villeneuve DL, Kahl MD, Makynen EA, Durhan EJ, Ankley GT: Linkage of biochemical responses to population-level effects: a case study with vitellogenin in the fathead minnow (Pimephales promelas). Environ Toxicol Chem 2007, 26(3):52I-527.

19. Kidd KA, Blanchfield PJ, Mills KH, Palace VP, Evans RE, Lazorchak JM, Flick RW: Collapse of a fish population after exposure to a synthetic estrogen. Proc Natl Acad Sci USA 2007, I 04(2I):8897-890I.

20. Filby AL, Neuparth T, Thorpe KL, Owen R, Galloway TS, Tyler CR: Health impacts of estrogens in the environment, considering complex mixture effects. Environ Health Perspect 2007, II5(I2): I704-1710.

2I. Filby AL, Thorpe KL, Maack G, Tyler CR: Gene expression profiles revealing the mechanisms of anti-androgen- and estrogeninduced feminization in fish. Aquat Toxicol 2007, 8I (2):2 I 9-23I.

22. Martyniuk CJ, Gerrie ER, Popesku JT, Ekker M, Trudeau VL: Microarray analysis in the zebrafish (Danio rerio) liver and telencephalon after exposure to low concentration of I7alphaethinylestradiol. Aquatic Toxicology 2007, 84(1):38-49.

23. Thomas P, Dressing G, Pang $Y$, Berg H, Tubbs C, Benninghoff $A$, Doughty K: Progestin, estrogen and androgen G-protein coupled receptors in fish gonads. Steroids 2006, $71(4): 310-316$.

24. Braun AM, Thomas P: Androgens inhibit estradiol-I 7beta synthesis in Atlantic croaker (Micropogonias undulatus) ovaries by a nongenomic mechanism initiated at the cell surface. Biol Reprod 2003, 69(5): 1642-1650

25. Loomis AK, Thomas P: Effects of estrogens and xenoestrogens on androgen production by Atlantic croaker testes in vitro: evidence for a nongenomic action mediated by an estrogen membrane receptor. Biol Reprod 2000, 62(4):995-1004.

26. Thomas $P$, Doughty K: Disruption of rapid, nongenomic steroid actions by environmental chemicals: interference with progestin stimulation of sperm motility in Atlantic croaker. Environ Sci Technol 2004, 38(23):6328-6332.

27. Braun AM, Thomas P: Biochemical characterization of a membrane androgen receptor in the ovary of the Atlantic croaker (Micropogonias undulatus). Biol Reprod 2004, 7 I (I): I46-155.

28. Patino R, Thomas $P$ : Characterization of membrane receptor activity for 17 alpha, 20 beta, 21 -trihydroxy-4-pregnen-3-one in ovaries of spotted seatrout (Cynoscion nebulosus). Gen Comp Endocrinol 1990, 78(2):204-217.

29. Dukes M, Chester R, Yarwood L, Wakeling AE: Effects of a nonsteroidal pure antioestrogen, ZM I89, I54, on oestrogen target organs of the rat including bones. J Endocrinol 1994, 141(2):335-341.

30. Marlatt VL, Hewitt LM, Kraak G Van Der: Utility of in vitro test methods to assess the activity of xenoestrogens in fish. Environ Toxicol Chem 2006, 25( I 2):3204-32I2.

31. Sabo-Attwood T, Blum JL, Kroll KJ, Patel V, Birkholz D, Szabo NJ, Fisher SZ, McKenna R, Campbell-Thompson M, Denslow ND: Distinct expression and activity profiles of largemouth bass (Micropterus salmoides) estrogen receptors in response to estradiol and nonylphenol. J Mol Endocrinol 2007, 39(4):223-237.

32. Sismondi P, Biglia N, Ponzone R, Fuso L, Scafoglio C, Cicatiello L, Ravo $M$, Weisz A, Cimino D, Altobelli G, et al.: Influence of estrogens and antiestrogens on the expression of selected hormoneresponsive genes. Maturitas 2007, 57(I):50-55.

33. Wu F, Xu R, Martin J, Safe S: In vivo profiling of estrogen receptor/specificity protein-dependent transactivation. Endocrinology 2008, I 49(I I):5696-5705.

34. Morales A, Gonzalez M, Marin R, Diaz M, Alonso R: Estrogen inhibition of norepinephrine responsiveness is initiated at the plasma membrane of GnRH-producing GT I-7 cells. J Endocrinol 2007, 194(I): 193-200.

35. Pang $Y$, Dong J, Thomas P: Estrogen signaling characteristics of Atlantic croaker G protein-coupled receptor 30 (GPR30) 
and evidence it is involved in maintenance of oocyte meiotic arrest. Endocrinology 2008, 149(7):3410-3426.

36. Hawkins MB, Thornton JW, Crews D, Skipper JK, Dotte A, Thomas $P$ : Identification of a third distinct estrogen receptor and reclassification of estrogen receptors in teleosts. Proc Natl Acad Sci USA 2000, 97(20): 1075I-10756.

37. Nagler J], Cavileer T, Sullivan J, Cyr DG, Rexroad C 3rd: The complete nuclear estrogen receptor family in the rainbow trout: discovery of the novel ERalpha2 and both ERbeta isoforms. Gene 2007, 392(I-2): 164-173.

38. Sabo-Attwood T, Kroll KJ, Denslow ND: Differential expression of largemouth bass (Micropterus salmoides) estrogen receptor isotypes alpha, beta, and gamma by estradiol. Mol Cell Endocrinol 2004, 2 1 8(I-2): 107-1 I8.

39. Jukosky JA, Watzin MC, Leiter JC: The effects of environmentally relevant mixtures of estrogens on Japanese medaka (Oryzias latipes) reproduction. Aquat Toxicol 2008, 86(2):323-331.

40. Lin LL, Janz DM: Effects of binary mixtures of xenoestrogens on gonadal development and reproduction in zebrafish. Aquat Toxicol 2006, 80(4):382-395

4I. Sun L, Zha J, Wang Z: Effects of binary mixtures of estrogen and antiestrogens on Japanese medaka (Oryzias latipes). Aquat Toxicol 2009, 93(I):83-89.

42. Villeneuve DL, Larkin P, Knoebl I, Miracle AL, Kahl MD, Jensen KM, Makynen EA, Durhan EJ, Carter BJ, Denslow ND, et al.: A graphical systems model to facilitate hypothesis-driven ecotoxicogenomics research on the teleost brain-pituitary-gonadal axis. Environ Sci Technol 2007, 4 I (I):32I-330.

43. Desbrow C, Routledge EJ, Brighty GC, Sumpter JP, Waldock M: Identification of estrogenic chemicals in STW effluent. I. Chemical fractionation and in vitro biological screening. Environmental Science \& Technology 1998, 32(I I): I549-I558.

44. Kashiwada S, Ishikawa H, Miyamoto N, Ohnishi Y, Magara Y: Fish test for endocrine-disruption and estimation of water quality of Japanese rivers. Water Res 2002, 36(8):2161-2I66.

45. Dukes M, Chester R, Yarwood L, Wakeling AE: Effects of a nonsteroidal pure antiestrogen, ZM- $\mid 89,154$, on estrogen target organs of the rat including bones. J Endocrinol 1994, | 4 I(2):335-34|.

46. MacLatchy DL, Courtenay SC, Rice CD, Kraak GJ Van der: Development of a short-term reproductive endocrine bioassay using steroid hormone and vitellogenin end points in the estuarine mummichog (Fundulus heteroclitus). Environ Toxicol Chem 2003, 22(5):996-1008.

47. Panter G, Hutchinson T, Länge R, Lye C, JP S, Zerulla M, Tyler C Utility of a juvenile fathead minnow screening assay for detecting (anti-) estrogenic substances. Environmental Toxicology and Chemistry 2002, 2 I(2):319-326.

48. Nikitin A, Egorov S, Daraselia N, Mazo I: Pathway studio - the analysis and navigation of molecular networks. Bioinformatics 2003, I ( $(16): 2155-2157$

49. Wong MK, Ge W, Woo NY: Positive feedback of hepatic angiotensinogen expression in silver sea bream (Sparus sarba). Mol Cell Endocrinol 2007, 263(I-2): I03-III.

50. Krattenmacher R, Knauthe R, Parczyk K, Walker A, Hilgenfeldt U, Fritzemeier $\mathrm{KH}$ : Estrogen action on hepatic synthesis of angiotensinogen and IGF-I: direct and indirect estrogen effects. J Steroid Biochem Mol Biol 1994, 48(2-3):207-2I4.

5I. Samsioe G: The endometrium: effects of estrogen and estrogen-progestogen replacement therapy. Int J Fertil Menopausal Stud 1994, 39(Suppl 2):84-92.

52. Heikaus S, Winterhager E, Traub O, Grummer R: Responsiveness of endometrial genes Connexin26, Connexin43, C3 and clusterin to primary estrogen, selective estrogen receptor modulators, phyto- and xenoestrogens. I Mol Endocrinol 2002, 29(2):239-249.

53. Jin G, Howe PH: Transforming growth factor beta regulates clusterin gene expression via modulation of transcription factor c-Fos. Eur J Biochem 1999, 263(2):534-542.

54. Londou A, Mikrou A, Zarkadis IK: Cloning and characterization of two clusterin isoforms in rainbow trout. Mol Immunol 2008, 45(2):470-478.

55. Wong P, Pineault J, Lakins J, Taillefer D, Leger J, Wang C, Tenniswood M: Genomic organization and expression of the rat TRPM-2 (clusterin) gene, a gene implicated in apoptosis. I Biol Chem 1993, 268(7):502|-503।.
56. Munoz-Canoves P, Vik DP, Tack BF: Mapping of a retinoic acidresponsive element in the promoter region of the complement factor H gene. J Biol Chem 1990, 265(33):20065-20068.

57. Wang DY, McKague B, Liss SN, Edwards EA: Gene expression profiles for detecting and distinguishing potential endocrine-disrupting compounds in environmental samples. Environ Sc Technol 2004, 38(23):6396-6406.

58. Chaudhary J, Sadler-Riggleman I, Ague JM, Skinner MK: The helixloop-helix inhibitor of differentiation (ID) proteins induce post-mitotic terminally differentiated Sertoli cells to reenter the cell cycle and proliferate. Biol Reprod 2005, 72(5): 1205-1217.

59. Dong YL, Vegiraju S, Chauhan M, Yallampalli C: Expression of calcitonin gene-related peptide receptor components, calcitonin receptor-like receptor and receptor activity modifying protein $I$, in the rat placenta during pregnancy and their cellular localization. Mol Hum Reprod 2003, 9(8):48I -490.

60. Zhang L, Rees MC, Bicknell R: The isolation and long-term culture of normal human endometrial epithelium and stroma. Expression of mRNAs for angiogenic polypeptides basally and on oestrogen and progesterone challenges. J Cell Sci I995, I 08(Pt I):323-33I.

61. Castro-Caldas M, Duarte CB, Carvalho AR, Lopes MC: I7betaestradiol promotes the synthesis and the secretion of annexin I in the CCRF-CEM human cell line. Mediators Inflamm 200I, I0(5):245-25।.

62. Huang EJ, Wu CC, Lee SD, Chen JH, Liu JY, Ko JL, Lin JA, Lu MC, Chen LM, Huang CY, et al:: Opposing action of estrogen receptors alpha and beta on tumor necrosis factor-alpha gene expression and caspase-8-mediated apoptotic effects in HA22T cells. Mol Cell Biochem 2006, 287(I-2): I37-I 45.

63. Stevens TA, Meech R: BARX2 and estrogen receptor-alpha (ESRI) co-ordinately regulate the production of alternatively spliced ESRI isoforms and control breast cancer cell growth and invasion. Oncogene 2006, 25(39):5426-5435

64. Shah BH: Estrogen stimulation of COX-2-derived PGI2 confers atheroprotection. Trends Endocrinol Metab 2005, 16(5): 199-20|

65. Durbin JE, Hackenmiller R, Simon MC, Levy DE: Targeted disruption of the mouse Stat I gene results in compromised innate immunity to viral disease. Cell 1996, 84(3):443-450.

66. Kim HS, Lee MS: STATI as a key modulator of cell death. Cell Signal 2007, 19(3):454-465

67. Shang $Y$, Baumrucker $C R$, Green $M H$ : The induction and activation of STATI by all-trans-retinoic acid are mediated by RAR beta signaling pathways in breast cancer cells. Oncogene 1999, I8(48):6725-6732.

68. Zhou Q, Atadja P, Davidson NE: Histone deacetylase inhibitor LBH589 reactivates silenced estrogen receptor alpha (ER) gene expression without loss of DNA hypermethylation. Cancer Biol Ther 2007, 6(I):64-69.

69. Blair HC, Robinson LJ, Zaidi M: Osteoclast signalling pathways. Biochem Biophys Res Commun 2005, 328(3):728-738.

70. Boon LM, Mulliken JB, Vikkula M: RASAI: variable phenotype with capillary and arteriovenous malformations. Curr Opin Genet Dev 2005, I 5(3):265-269.

71. Hikima J, Lennard ML, Wilson MR, Miller NW, Clem LW, Warr GW: Evolution of vertebrate $E$ protein transcription factors: comparative analysis of the $E$ protein gene family in Takifugu rubripes and humans. Physiol Genomics 2005, 2 I (2): I44-I5I.

72. Hurteau G], Carlson JA, Spivack SD, Brock G]: Overexpression of the microRNA hsa-miR-200c leads to reduced expression of transcription factor 8 and increased expression of E-cadherin. Cancer Res 2007, 67(I7):7972-7976.

73. Drabsch Y, Hugo H, Zhang R, Dowhan DH, Miao YR, Gewirtz AM, Barry SC, Ramsay RG, Gonda T]: Mechanism of and requirement for estrogen-regulated MYB expression in estrogen-receptor-positive breast cancer cells. Proc Natl Acad Sci USA 2007, 104(34): 1 3762-13767.

74. Urano A, Endoh M, Wada T, Morikawa Y, Itoh M, Kataoka Y, Taki T, Akazawa $\mathrm{H}$, Nakajima H, Komuro I, et al.: Infertility with defective spermiogenesis in mice lacking AF5q3I, the target of chromosomal translocation in human infant leukemia. Mol Cell Biol 2005, 25(I 5):6834-6845. 
75. Hogarth CA, Calanni S, Jans DA, Loveland KL: Importin alpha mRNAs have distinct expression profiles during spermatogenesis. Dev Dyn 2006, 235(I):253-262.

76. Yoon SO, Shin S, Liu Y, Ballif BA, Woo MS, Gygi SP, Blenis J: Ranbinding protein 3 phosphorylation links the Ras and PI3kinase pathways to nucleocytoplasmic transport. Mol Cell 2008, 29(3):362-375

77. Fang WB, Brantley-Sieders DM, Hwang Y, Ham A, Chen J: Identification and functional analysis of phosphorylated tyrosine residues within EphA2 receptor tyrosine kinase. J Biol Chem 2008, 283(23): 160I7-16026.

78. Hemming JM, Waller WT, Chow MC, Denslow ND, Venables B: Assessment of the estrogenicity and toxicity of a domestic wastewater effluent flowing through a constructed wetland system using biomarkers in male fathead minnows (Pimephales promelas rafinesque, 1820). Environ Toxicol Chem 200I, 20(10):2268-2275.

79. Jensen KM, Korte JJ, Kahl MD, Pasha MS, Ankley GT: Aspects of basic reproductive biology and endocrinology in the fathead minnow (Pimephales promelas). Comp Biochem Physiol C Toxicol Pharmacol 200I, I 28(I): |27-I4I.

80. Sokal R, Rohlf F: Biometry. New York: Freeman and Company; 1995.

8I. Garcia-Reyero N, Barber DS, Gross TS, Johnson KG, Sepulveda MS, Szabo NJ, Denslow ND: Dietary exposure of largemouth bass to OCPs changes expression of genes important for reproduction. Aquat Toxicol 2006, 78(4):358-369.

82. Zahurak M, Parmigiani G, Yu W, Scharpf RB, Berman D, Schaeffer E, Shabbeer S, Cope L: Pre-processing Agilent microarray data. BMC Bioinformatics 2007, 8: 142.

83. Benjamini $Y$, Hochberg $Y$ : Controlling the false discovery rate a practical and powerful approach to multiple testing. J Roy Stat Soc B Met 1995, 57(I):289-300

84. Ankley GT, Jensen KM, Kahl MD, Makynen EA, Blake LS, Greene KI Johnson RD, Villeneuve DL: Ketoconazole in the fathead minnow (Pimephales promelas): reproductive toxicity and biological compensation. Environ Toxicol Chem 2007 26(6): $1214-1223$.

85. Villeneuve DL, Blake LS, Brodin JD, Greene KJ, Knoebl I, Miracle AL, Martinovic D, Ankley GT: Transcription of key genes regulating gonadal steroidogenesis in control and ketoconazole- or vinclozolin-exposed fathead minnows. Toxicol Sci 2007 98(2):395-407.

86. Martinovic D, Blake LS, Durhan EJ, Greene KJ, Kahl MD, Jensen KM, Makynen EA, Villeneuve DL, Ankley GT: Reproductive toxicity of vinclozolin in the fathead minnow: confirming an anti-androgenic mode of action. Environ Toxicol Chem 2008, 27(2):478-488.

87. Villeneuve DL, Knoebl I, Kahl MD, Jensen KM, Hammermeister DE, Greene KJ, Blake LS, Ankley GT: Relationship between brain and ovary aromatase activity and isoform-specific aromatase mRNA expression in the fathead minnow (Pimephales promelas). Aquat Toxicol 2006, 76(3-4):353-368
Publish with Bio Med Central and every scientist can read your work free of charge

"BioMed Central will be the most significant development for disseminating the results of biomedical research in our lifetime. "

Sir Paul Nurse, Cancer Research UK

Your research papers will be:

- available free of charge to the entire biomedical community

- peer reviewed and published immediately upon acceptance

- cited in PubMed and archived on PubMed Central

- yours - you keep the copyright
BioMedcentral 